US Army Corps of Engineers ${ }_{\circledast}$ Engineer Research and Development Center

Aquatic Nuisance Species Research Program

\title{
Invasive Animal Species in Marine and Estuarine Environments: Biology and Ecology
}

Gary L. Ray

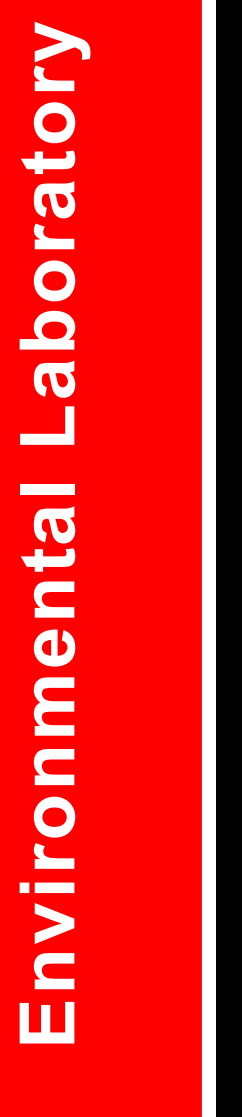




\section{Invasive Animal Species in Marine and Estuarine Environments: Biology and Ecology}

Gary L. Ray

Environmental Laboratory

U.S. Army Engineer Research and Development Center 3909 Halls Ferry Road

Vicksburg, MS 39180-6199

Final report

Approved for public release; distribution is unlimited

Prepared for Headquarters, U. S. Army Corps of Engineers

Washington, DC 20314-1000 


\begin{abstract}
Every year new animal species are inadvertently or intentionally introduced into the marine and estuarine waters of the United States. Originating overseas and from other U.S. waters, invasive species have the potential to disrupt local ecosystems, fisheries, and human infrastructure. Biological invasions directly impact the mission of the U.S. Army Corps of Engineers (USACE) through its responsibilities in maintenance of our nation's waterways, erosion control, water resource management, and estuarine and marine habitat restoration. This report describes the biology and ecology of invasive marine animals and identifies specific organisms that may pose a threat to USACE activities. This includes species already established in U.S. waters and those not yet present that are likely to pose a threat if introduced.
\end{abstract}

DISCLAIMER: The contents of this report are not to be used for advertising, publication, or promotional purposes. Citation of trade names does not constitute an official endorsement or approval of the use of such commercial products. All product names and trademarks cited are the property of their respective owners. The findings of this report are not to be construed as an official Department of the Army position unless so designated by other authorized documents. 


\section{Contents}

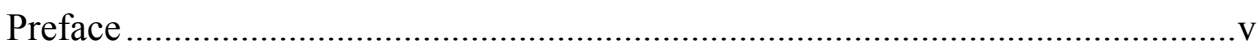

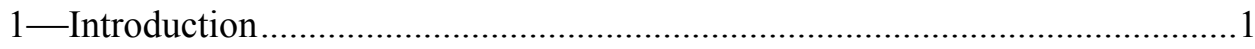

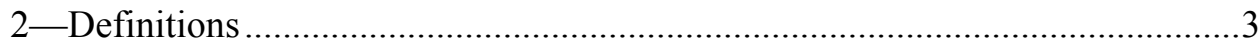

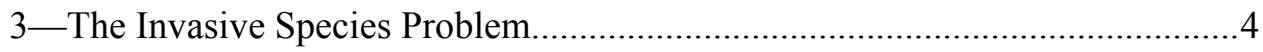

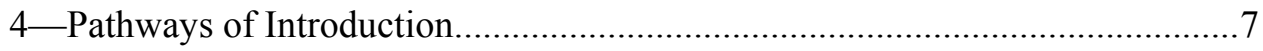

5 -Colonization and Dispersal .................................................................

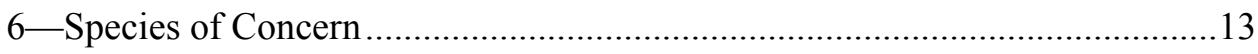

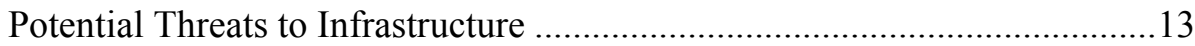

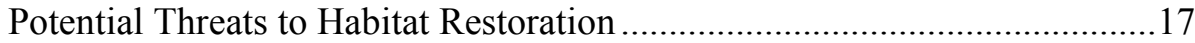

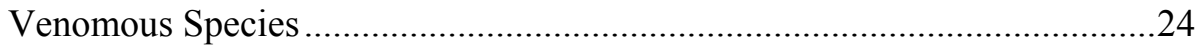

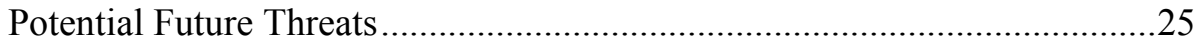

Other Species That Merit Consideration..................................................26

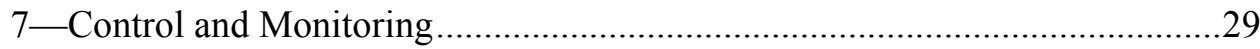

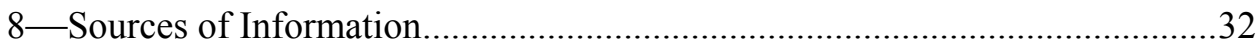

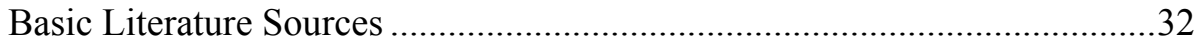

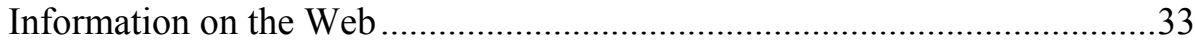

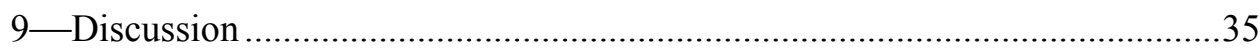

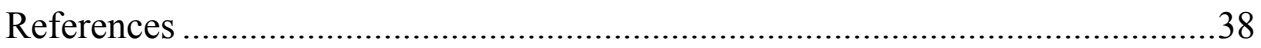

SF 298

\section{List of Figures}

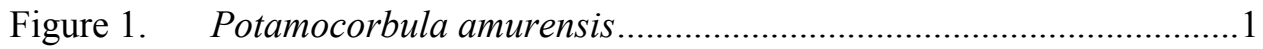


Figure 2. Chinese Mitten Crab, Eriocheir sinensis .......................................13

Figure 3. The Green Mussel, Perna viridis.....................................................15

Figure 4. The Brown Mussel, Perna perna ...................................................16

Figure 5. The Asian Date Mussel, Musculista senhousi ................................17

Figure 6. The European Green Crab, Carcinus maenas .................................18

Figure 7. The Veined Rapa Whelk, Rapana venosa .......................................21

Figure 8. The Green Porcelain Crab, Petrolisthes armatus ...........................22

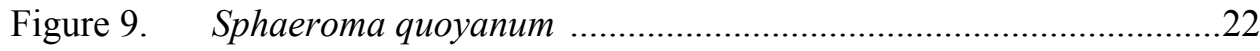

Figure 10. Marsh erosion due to burrowing …............................................23

Figure 11. The Australian Jellyfish, Phylloriza punctata ................................24

Figure 12. The Lionfish, Pterois volitans ..................................................25 


\section{Preface}

This report was authorized by Headquarters, U.S. Army Corps of Engineers (HQUSACE), as part of the Aquatic Nuisance Species Research Program (ANSRP). Comments should be submitted via the Internet at the following address: http://el.erdc.usace.army.mil/wetlands/hgmhp.html.

Written comments should be addressed to:

Department of the Army

Engineer Research and Development Center

CEERD-EE-W

3909 Halls Ferry Road

Vicksburg, MS 39180-6199

This report was written by Dr. Gary L. Ray, Environmental Laboratory (EL), Vicksburg, MS, U.S. Army Engineer Research and Development Center (ERDC). Mr. Dave Mathis, CERD-C, was the ANSRP Coordinator at the Directorate of Research and Development, HQUSACE; Mr. Joseph R. Wilson, CECW-EW, served as the ANSRP Technical Monitor's Representative; Dr. Alfred F. Cofrancesco, EL, served as Technical Director; and Mr. Glenn G. Rhett, EL, was the ANSRP Program Manager.

This work took place under the general supervision of Dr. Morris Mauney, Jr., Chief, Wetlands and Coastal Ecology Branch; Dr. David J. Tazik, Chief, Ecosystem Evaluation and Engineering Division; and Dr. Elizabeth C. Fleming, Acting Director, EL.

At the time of publication of this report, COL James R. Rowan, EN, was Commander and Executive Director of ERDC. Dr. James R. Houston was Director. 


\section{Introduction}

In 1987, scientists examining bottom communities in San Francisco Bay encountered a species of clam not previously found there. Eventually identified as the Amur River Corbula clam, Potamocorbula amurensis (Figure 1), a resident of Chinese, Japanese, and Korean waters, the roughly $2.5-\mathrm{cm}-(1-i n .-)$ long clam quickly spread throughout the estuary. As it spread it displaced resident benthic assemblages (Carlton et al. 1990, Nichols et al. 1990). By the early 1990's, it had reached sufficient densities that significant declines in bay phytoplankton, an important link in the bay food chain, were attributed to its filter-feeding activities (Alpine and Cloern 1992). Before the clam invasion, phytoplankton had a small annual peak in abundance in early spring and a larger one in late summer. After introduction, the spring peak declined, and the summer peak virtually disappeared. The reduction in phytoplankton availability had ramifications throughout the bay food web, including reduced zooplankton and fish abundance and altered feeding habits of resident fish (Kimmerer et al. 1994, Feyrer et al. 2003).

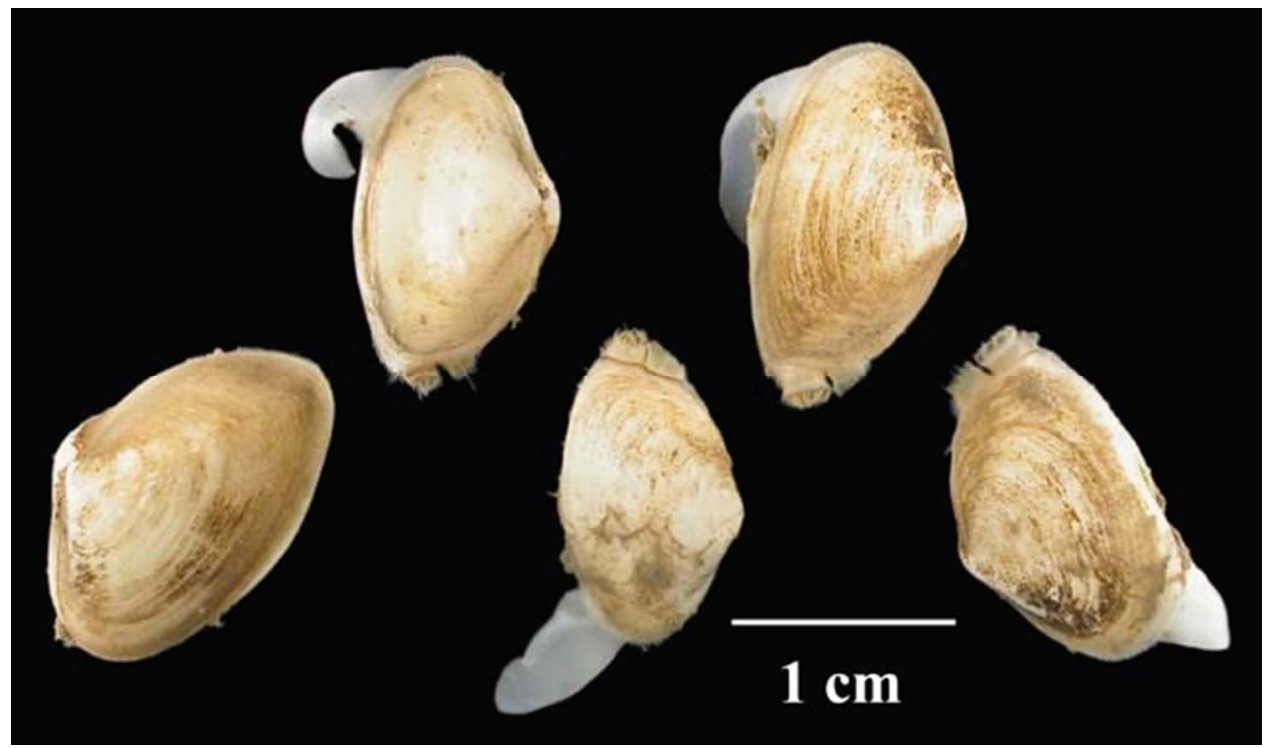

Figure 1. Potamocorbula amurensis (image courtesy of California Academy of Sciences) 
The introduction and subsequent spread of this one species altered, perhaps permanently, the ecology of the entire estuary. This sequence of events has been repeated elsewhere with increasing frequency in recent years. Every year, new animal species are inadvertently or intentionally introduced into the marine and estuarine waters of the United States. Introduced species now make up more than 4 percent of the species and 27 percent of total abundance of macroinvertebrates in Southern California benthic assemblages and 2-11 percent of the species and 3-22 percent of abundance in those in Northern California, Oregon, and Washington estuaries (Lee et al. 2003, Velarde et al. 2003). For example, introduced copepod species also dominate the zooplankton of many Pacific Northwest estuaries (Cordell and Morrison 1996).

In San Francisco Bay, an average of one new species was introduced every 14 weeks between 1961 and 1995, and as of 1998, there were 164 introduced marine and estuarine species in the bay (Cohen and Carlton 1998). At least 196 introduced plant and fish species have been identified in Chesapeake Bay (Ruiz et al. 1999). A total of 298 introduced marine and estuarine species have been documented to occur in North America (Ruiz et al. 2000).

Although most introduced species fail to survive or spread, and not all that become established necessarily pose a threat, the sheer number of species potentially entering our coastal waters each year raises serious concerns. Whether they originate overseas or from other U.S. waters, invasive species have the potential for serious disruption of local ecosystems, fisheries, and human infrastructure. Such invasions directly impact the mission of the U.S. Army Corps of Engineers (USACE), through its responsibilities in construction and maintenance of our nation's harbors, ports and waterways, erosion control, management of water resources, and wetland and coastal habitat restoration. In the following report, the biology and ecology of invasive marine and estuarine animals are described and specific organisms that may pose a threat to USACE activities are identified. These include species introduced in the distant past (e.g., European Green Crab, Carcinus maenas), those recently arrived, and those that seem likely to be of concern if introduced in the United States. 


\section{Definitions}

What is an invasive species? The term is officially defined in Executive Order 13112 (Federal Register 1999) as "an alien species whose introduction does or is likely to cause economic or environmental harm to human health." Thus, an invasive species is one that is not native to a region and has the potential to cause deleterious impacts. A number of other terms are used synonymously with invasive species. The most common term, introduced species, indicates an organism that is not native to a region. The term itself is neutral and does not indicate if the species poses a threat, although there is often the unstated assumption that it could. The same is true for the phrase nonindigenous species or NIS. This term is widely used and simply indicates that the species is not indigenous. The terms alien, nonnative, and exotic have similar usages. The terms pest and weed species are often used for estuarine or marine animals infesting shellfish or mariculture operations; however, just because a species is considered to be a pest or weed does not automatically mean it is nonindigenous. Sponges and worms, which bore into oyster shell and mud shrimp whose burrowing may bury oysters in sediment, are considered pests by the nation's oyster industry, and yet they are natural components of the native oyster community. 


\section{The Invasive Species Problem}

The task of detecting, identifying, and assessing the potential impact of invasive estuarine and marine animals is daunting on several levels. First, there are surprisingly few comprehensive studies from which to determine if a species is native or introduced. Only a handful of estuaries, such as San Francisco Bay and Chesapeake Bay, have been thoroughly studied (e.g., Cohen and Carlton 1995, Ruiz et al. 1999), although substantial efforts are underway to address this issue. For instance, surveys of nonindigenous species have been completed for Humboldt Bay, California (Boyd et al. 2002) and portions of Hawaii (DeFelice et al. 2001). Monitoring programs for NIS have been instituted in San Francisco Bay, Puget Sound and surrounding estuaries, New England, and Florida. Nonetheless, even in the best studies taxonomic coverage is uneven. Understanding of what species are native to a locality is often governed by the taxonomic interests (e.g., fish, mollusks, worms, etc.) of specialists studying the region and the degree to which the area has been sampled. For instance, although polychaete worms are dominant members of estuarine and marine bottom communities, comprehensive taxonomic guides for the northern Gulf of Mexico have only been available since 1984 (e.g., Uebelacker and Johnson 1984). A related concern is that the specimens necessary to evaluate the fauna of a particular locale may be dispersed among the collections of a variety of entities and therefore difficult to access (Hutchings and Glasby 2004). While the National Museum (USNM) serves as the central repository for collections in the United States, not all organizations conducting faunal studies, including many governmental agencies and private consulting firms, routinely deposit voucher specimens with USNM. To complicate the matter further, the results of many such studies often go unpublished or are published in the so-called "gray" scientific literature, limiting awareness even among experts.

As a rule, information on both the geographic distribution and taxonomy of a group is a function of the organism's size: the smaller the animal, the less information is available. Thus our knowledge of small organisms such as nematodes (average length $\sim 1-2 \mathrm{~mm}$ ) is far less than that for mollusks or fishes (e.g., Snelgrove 1997 and 1999). A corollary to the size-dependence of taxonomic information is the correlation between the commercial or recreational importance of a species and what is known about it. There is more information on the biology of fish, crabs, and mollusks than for annelids and far more about edible species (e.g., salmon, blue crabs, and oysters) than much more numerous 
inedible species. In addition, there is a continuing decline in the number of scientists specializing in taxonomy (Winston and Metzger 1998). The decline appears to be part of a broader shift away from systematics and life history studies common prior to the 1950's to a more recent focus on cellular, molecular, and evolutionary studies (Wilson 1989).

The lack of data on species distributions and the paucity of taxonomic information can combine to make detection and identification of invading species extremely difficult. Even when a suspect species is detected, it is not always possible to determine if it is truly an introduced species. Many species have wide distributions and most naturally extend their distribution range over time or do so temporarily in response to short-term climatic changes (Elton 1958). An important step in determining whether or not a species is introduced or has the potential to become invasive is to understand how long it has been in a particular locality and its relative abundance. In the absence of data collected over long time periods, it may not be possible to distinguish between native and introduced species. Carlton (1996) has described species with uncertain origins as cryptogenic and estimates that in San Francisco Bay there is approximately one cryptogenic species for every two introduced species. This includes many of the dominant organisms such the polychaete Streblospio benedicti (Cohen and Carlson 1995).

The problem is further complicated by the variety of organisms that can become invasive species. Virtually any species has the potential to become invasive once it is removed from its native range. Everything from bacteria and viruses to algae, invertebrates, and fish have been found in the ballast of oceangoing ships and therefore have the potential to be introduced outside their native ranges (Gollasch et al. 2002). In practice, mollusks, crustaceans, and polychaete worms dominate estuarine and marine invasive species lists; however, this may reflect their ease of detection rather than their representiveness. It is ultimately an issue of an organism's innate biological characteristics (e.g., reproductive capacity, growth rate, etc.) and not its taxonomic associations that determine if it has the capacity to become an invasive species.

Erlich (1989) and Williams and Meffe (1999) have summarized the characteristics common to successful invasive plant and animal species. Those that apply specifically to estuarine and marine animals include (a) abundant over a large native range, (b) diverse diet and habitat preferences, (c) short generation time, (d) high genetic variability, and (e) wide physiological tolerance. Based on our knowledge of these characteristics, why isn't it possible to predict which species are going to become invasive species? Unfortunately, these characteristics apply to a plethora of marine and estuarine animal species that occur globally, limiting our ability to detect candidate species. Furthermore, invasive species are not necessarily obvious in their native region. Factors such as predation, disease, parasites, and competition act to keep population levels in check. It is only when the species is transplanted to a new environment and released from such controls that it has the opportunity to become a problem (Torchin et al. 2003, Wolfe 2002). 
The ability to predict habitats likely to be invaded is somewhat better. Williams and Meffe (1999) list nine characteristics typical of invaded communities, seven of which are applicable to estuarine and marine habitats: (a) climate similar to source area of invading species, (b) recently disturbed, (c) low natural diversity, (d) no likely predators on invading species, (e) no native species morphologically similar to invading species, (f) low-connectance (relatively simple) food web, and (g) anthropogenically disturbed. Estuaries and sheltered coastal areas are among the most invaded habitats presumably due to the fact that they are naturally disturbed, low-diversity systems and historically the center of anthropogenic disturbance associated with seaborne transportation, industrial development, and urbanization. Ruiz et al. (2000) reported that high salinity estuarine environments $(>25 \mathrm{ppt})$ tend to more prone to invasion than low salinity areas. They found three to four times more NIS in high than low salinity waters in San Francisco Bay. Lee et al. (2003) subsequently reported that the estuarine maximum zone (mean $5 \mathrm{ppt}$ ), main estuarine community (mean $16 \mathrm{ppt}$ ), and marine muddy communities (mean $28 \mathrm{ppt}$ ) of San Francisco Bay had greater numbers of NIS than brackish-water areas or marine sands. In contrast, the majority of introduced species in Chesapeake Bay are found in the brackish mesohaline (5-15 ppt) portion of the estuary (Ruiz et al. 2000). In the Netherlands, Wolff (1999) found a far higher proportion of NIS in brackish waters than elsewhere. He postulated that this is due to the fact that brackish water species are more tolerant of conditions in ballast water (a major pathway for introduction), there are fewer species in brackish water to compete with potential invaders, and most of the Dutch ports (a major entry point for invading species) are in brackish waters. 


\section{Pathways of Introduction}

Sakai et al. (2001) described three stages necessary for a successful invasion: (a) introduction, (b) colonization and establishment, and (c) dispersal. Williamson and Fritter (1996) have suggested that the probability of success during introduction follows a rule of tens. Simply put, only one in ten introduced species survive; only one tenth of these become established and disperse; and only a tenth of the remaining represent threats. Invasive species can be introduced either intentionally or unintentionally by a variety of different mechanisms. Intentional introductions are generally associated with mariculture or commercial fisheries operations. For instance, the striped bass, Morone saxatilis, a native of the Atlantic coast, was intentionally introduced to California in 1879, and now supports a major sport fishery (Hassler 1988). It has expanded its range along the west coast from its initial introduction in San Francisco Bay south to Ensenada, Mexico and north to British Columbia (Forrester et al. 1972). The American oyster, Crassostrea virginica, was introduced to the Pacific coast to supplement declining stocks of local oyster species. Unfortunately, a number of other species may have been unintentionally introduced along with the oysters. These include the Atlantic oyster drill Urosalpinx cinerea, the slipper shells Crepidula fornicata and C. plana, the polychaete Polydora cornuta, and the salt marsh cordgrass Spartina alterniflora. Spartina, presumably used as packing material during shipment of the oysters, has since become an invasive plant species throughout the west coast. Likewise, a number of species have been unintentionally introduced to European waters during introductions of American, Pacific ( $C$. gigas), and New Zealand ( $C$. angulata) oysters, hard clams (Mercenaria mercenaria), and Manila clams (Tapes philippinarum) (Wolff and Reise 2002). While most of the unwanted introductions have failed to establish local populations, at least two species, the oyster drill U. cinerea and the slipper shell $C$. fornicata, have survived and become pest species. The Japanese brown algae Sargassum muticam has been introduced to areas as far apart as California and the Mediterranean Sea when used as packing for the Japanese oyster C. gigas (USGS 1998, Wolff and Reise 2002). There is presently a proposal to introduce the Pacific oyster $C$. gigas and the Japanese oyster $C$. arukensisis to Chesapeake Bay to improve water quality and supplement stocks of native oysters $(C$. virginica) ravished by disease and overfishing (Gottleib and Schweighofer 1996).

Unintentional introduction is probably the major source of entry for invasive species. Species able to attach to hard surfaces (e.g., barnacles) may be transported on ship hulls, pontoons of amphibious airplanes, drilling platforms, navigational buoys, floatation devices, anchors, chains, ropes, and flotsam or 
jetsam (Carlton 2001). They may also hitch a ride on nets, traps, trawls, or other gear associated with the fishing industry and recreational equipment (e.g., boat skis, SCUBA gear, wetsuits, boots, waders, etc.). Restaurants serving live seafood sometimes accidentally release animals or dispose of packing material and its attendant hitchhikers in an inappropriate manner. The same can be true in the live bait industry.

Prior to the advent of steel-hulled vessels in the early 1900's, wooden-hulled ships facilitated the introduction of wood-boring species such as the aptly named shipworm (Teredo sp.), barnacles, and other fouling species (Carlton and Hodder 1995). Use of dry ship's ballast (stones, rock, sand, or other materials) is believed to have facilitated the entry of the common periwinkle, Littorina littorea, from Europe. Now found from Chesapeake Bay to New England, this species has displaced the native snail Nassarius obsoletus (Brenchley and Carlton 1983), is a major influence on the intertidal distribution of seaweeds and other algae, and grazes heavily on salt marsh plants (Bertness 1984).

Recently, concern has been raised with the aquarium trade. Padilla and Williams (2004) indicate that in Florida, aquarium release is the single most important source of introduced species. Freshwater species represent the majority of the releases (148 out of 150 species); however, saltwater aquaria and "live rock" aquaria are becoming increasingly popular. Release of aquarium species either by aquarium dealers or hobbyists is virtually unregulated.

Ruiz et al. (2000) analyzed the likely sources and pathways for North American marine invasions and concluded that most invasive species are associated with shipping. They estimated that 60 percent of all invasive marine species on the Atlantic coast and 48 percent and 64 percent on the Pacific and Gulf coasts, respectively, could be attributed to some aspect of the shipping industry. The largest numbers of known invasive species occur on the Pacific coast with 53 percent coming from the Indo-Pacific and Western Atlantic. Only 7 percent originated from the Eastern Atlantic. On the Atlantic coast, 33 percent were of Indo-Pacific origin, and 19 percent came from the Eastern Atlantic. Both of these results reflect the port of origin for the majority of ships entering U.S. waters (i.e., most ships entering east coast ports originate in Europe, while those entering west coast ports tend to come from the Pacific Rim). The Atlantic coast also has the highest number of secondary invasive species (Ruiz et al. 2000). These are organisms that first established populations outside of their natural range after which their progeny supply propagules for further invasions. An example of such a stepping stone invasion is the marine gastropod Ocinebrellus (Cerastostoma) inornatus, a native of Japanese and Chinese waters first detected in the United States in 1924 and subsequently in European waters (Goulletquer et al. 2002). Martel et al. (2004) showed that European O. inornatus are genetically most closely related to Puget Sound populations, indicating they were derived from U.S. rather than native stocks.

The primary pathways of introduction to German waters have changed over time and vary among sites (Nehring 2002). Invasions of inland waters (mostly freshwater) are primarily the result of navigation canal construction. Introduction of only 6 of 35 nonindigenous species can be directly related to shipping 
with the rest appearing to be habitat expansions facilitated by the canals. On the North and Baltic Sea coasts, shipping is the primary pathway of introduction. Prior to the development of anti-fouling paints, most introductions were associated with hull fouling. Today, hull fouling and ballast water appear to be equally important.

The largest single source of shipping-related introduced species in the United States is ballast water (Carlton 1985, Lavoie et al. 1999). Ballast water is taken onboard vessels to reduce stress on the hull, provide stability (trim), aid in efficiency of propulsion and maneuverability by controlling the level to which the propeller, bow thruster, and rudder are submerged, reduce freeboard (the proportion of the hull exposed to the wind), compensate for consumption of water and fuel, provide for operational needs (e.g., keeping the ship at a constant height relative to cranes and other equipment used in loading and unloading), and clean holds and decks (Carlton et al. 1995). The total volume of ballast water carried onboard varies with the size of the ship. Small boats and coastal vessels generally carry less than a few hundred gallons, whereas modern bulk carriers or container ships may carry tens-of-millions of gallons (Carlton et al. 1995). Ballast water volume also varies over time, since the amount of cargo present, changing sea conditions, and other operational factors require periodic adjustment of ballast as a ship moves from port to port, loading and unloading cargo.

Water is pumped into the ballast tanks from the surrounding water body and likewise discharged overboard when necessary. Whatever living and non-living materials may be suspended in the water at the time end up in the ballast tanks. Entrained organisms can include holoplankton (permanent members of the plankton community such as copepods), meroplankton (larvae of bottom organisms which reside temporarily in the plankton), tychoplankton (bottom organisms incidentally suspended in the water column), floating or detached organisms, demersal species including fish and shrimp, benthic organisms brought in with bottom sediments, as well as bacteria, viruses, phytoplankton, and algae (Carlton et al. 1995). Species requiring a solid surface (e.g., barnacles) may be transported on the sides of cargo holds and ballast tanks or attached to wood and plastic debris that is pumped in with the ballast water or otherwise ends up in the hold. The precise assemblage present is a function of where and when ballast was added or removed from the tanks. Since cargo ships often visit multiple waypoints, the result can be a mix of organisms from various sources (Carlton 1985). Further complications can arise from the use of multiple ballast tanks making it difficult to predict which one(s) may be utilized at any given time during a voyage. Thus, when ballast is discharged, it can include a wide variety of organisms from multiple sources.

Survival of organisms once entrained in the ballast water is by no means guaranteed. The ballast water environment is generally lightless and characterized by variable dissolved oxygen concentrations, turbidity, salinity, and temperature (Carlton 1985). Water quality is dictated, to a large degree, by that of the original water source plus any additional water pumped into the tank during a voyage. Organisms in the ballast water will be exposed not only to contaminants present in the water sources but also to those generated onboard 
such as metals, grease, oil, and materials leaking from the cargo. Carlton et al. (1995) emphasize the potential importance of ballast tank corrosion due to sulphate-reducing bacteria. Such corrosion not only injures the tanks but also can contribute to low oxygen conditions and high concentrations of sulphides. Ballast water organisms are also exposed to potentially poor food quality and abundance as well as predators, competitors, and disease organisms also present in the ballast. Despite all of these factors, very few ships have ballast that is devoid of life. Carlton et al. (1995) reported that almost all vessels in Canadian, Australian, and U.S. studies of ballast water contained at least some organisms. They calculated that more than 500 species were present in these studies. For instance, Carlton and Geller (1993) detected 230 marine animals and an additional 137 other forms (e.g., bacteria, algae, etc.) in ships arriving in Coos Bay, Oregon from Japan. European ballast water studies have detected 990 species ranging from bacteria to fish as large as $15 \mathrm{~cm}$ (Minchlin and Gollasch 2002, Gollasch et al. 2002)

Ironically, attempts to limit water pollution associated with ballast water discharge by using separate ballast-specific tanks rather than a single generalpurpose tank may inadvertently result in greater survival rates among ballast water organisms. The shorter transit times of modern transport ships also improve the likelihood of survival by limiting the time spent in the ballast. Improvement in water quality conditions of many ports and harbors also contributes to the survival of discharged ballast water organisms. 


\section{Colonization and Dispersal}

Once transport has been survived, the next challenge is introduction into a new and potentially hostile environment. Initial survival may simply be a matter of luck. If an organism is transported into an unsuitable environment, for instance a marine species introduced into freshwater, it is unlikely to survive. If it is fortunate enough to be introduced into a suitable habitat it still has to survive a gauntlet of predators, competitors, and diseases. Native predators can take a considerable toll on introduced species. Reutsch (1998) has shown experimentally that Pteropurpura festiva, a muricid snail native to Southern California, actually prefers feeding on the introduced mussel Musculista senhousia to its native prey. The green crab Carcinus maenas, now an invasive species on both the east and west coasts of the United States, has encountered significant resistance to expansions in the Pacific Northwest where the red rock crab Cancer productus actively preys on it (Hunt and Yamada 2003). Introduced species generally do best where there is an empty niche (a niche space presently unexploited by the native fauna).

Another significant challenge to colonization is the number of specimens or propagules of a species that successfully enter the new habitat at any one time. If the species reproduces sexually, then at least one of each sex must be introduced in fairly close proximity. If all propagules are of one sex, or they are too far apart to successfully mate or for their gametes to come into contact, colonization will ultimately be unsuccessful. If there are too few initial colonizers and therefore low genetic variability, the population will eventually fail due to genetic bottlenecks resulting from inbreeding. Limited genetic variability may also restrict the ability of the population to exploit new niches or habitats. Successful introductions often require multiple episodes of introduction in order to accumulate sufficient animals to ensure reproduction and a large genetic pool.

Once an introduced species has survived transport and initial colonization, it may experience a lag time prior to population expansion. This is a function of the time necessary for the new colonists to physiologically adjust to the new environment, to mature and to produce sufficient new colonists to initiate further population growth. If there is sufficient resistance from native predators or competitors, population growth may be restrained. Time lags may also reflect the availability of critical resources or the occurrence of species-specific environmental requirements. For instance, a newly arrived species requiring a pulse of low salinity or a peak in phytoplankton production to initiate reproduction might have to wait for these conditions to be met. 
Species that have the greatest success during colonization and dispersal are those with multiple feeding and reproductive strategies. For example, the cryptogenic spionid polychaete Streblospio benedicti, thought to be native to the U.S. east coast, is now a dominant member of soft-bottom estuarine communities on all three coasts of the continental United States. It is able to adjust its feeding habit from sediment-surface feeding to filter feeding depending on food availability and current strength (Dauer 1984). It is also capable of producing either planktonic or benthic larvae, thus accruing the advantages of both dispersal modes (Levin 1984, Levin et al. 1987). Planktonic larvae allow for dispersal over wide areas, while benthic larvae permit exploitation of resources in close proximity to the adult population. Self-fertilizing or asexually reproducing species are particularly good colonizing species (Sakai et al. 2001).

The success of an introduced species may also be related to the ability to outcompete native species for resources such as food or space. Batillaria attramentaria (= zonalis), a snail introduced to the Pacific Northwest during importation of Japanese oysters (C. gigas), is far more efficient at food conversion than native snails, allowing it to achieve densities as high as $10,000 / \mathrm{m}^{2}$ (Byers 2000a). Batillaria does not ingest more food/gram of snail but simply utilizes the food more efficiently. Stachowicz et al. (2002) have shown that the key to the success of tunicate species invading hard bottom communities in New England is water temperature and the timing of recruitment. Examining the recruitment and growth of hard bottom communities over several years, they found that during warm years invading tunicate species settled sooner and grew faster than native species. Average water temperature did not seem to be as important as annual maximum and minimum temperatures. The authors hypothesized that as global ocean temperatures increase, invasive species may begin to dominate these communities. 


\section{Species of Concern}

This chapter summarizes the biology and ecology of individual invasive estuarine and marine animals species. The list of species is not comprehensive, but represents those that in the opinion of the author potentially pose a threat to USACE activities. Species are divided into four classes: those that represent a threat to infrastructure (e.g., navigation or water control structures), those that may interfere with habitat restoration efforts, venomous species, and those not presently in U.S. waters but candidates for concern. In addition, several species that do not directly impact Corps projects, but are of general concern, are described. The list of species threatening infrastructure is relatively small and contains mostly species that destabilize earthen water-control works or foul coastal structures (i.e., piers, water intake tunnels, etc.). The second list is much longer and contains species that undermine efforts to restore wetlands, oyster beds, seagrass beds, and other coastal habitats or prevent the recruitment of natural biotic assemblages to recently dredged or placed sediments. More comprehensive lists of invasive marine and estuarine animals are available elsewhere (see Chapter 8, "Sources of Information") or will be provided in future reports in this series.

\section{Potential Threats to Infrastructure}

\author{
The Chinese \\ mitten crab \\ Eriocheir sinensis \\ (Figure 2) first \\ appeared as an \\ invasive species in \\ German waterways \\ during the early \\ 1900 's and has \\ since spread \\ through much of \\ Europe (Clark et al. \\ 1998). Detected in \\ Lake Erie in 1973 \\ (Nepszy and Leach \\ 1975), it has since
}

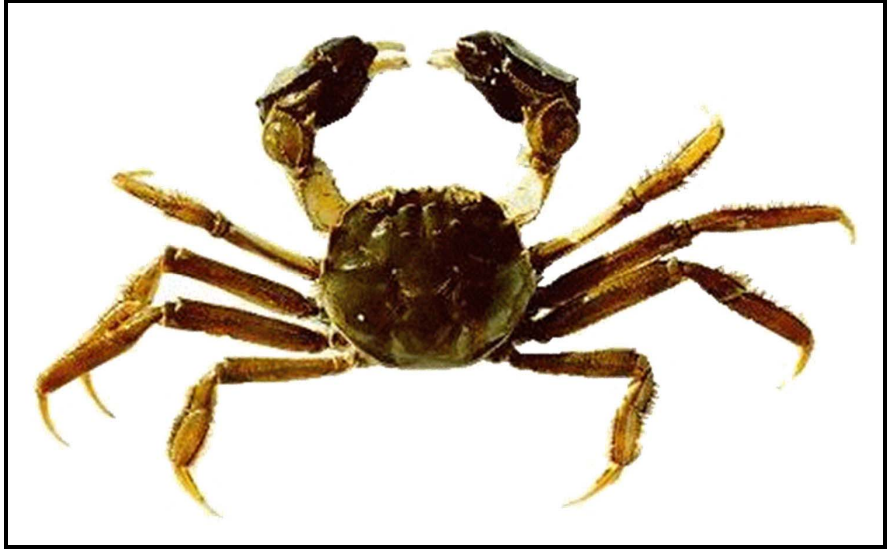

Figure 2. Chinese Mitten Crab, Eriocheir sinensis (image courtesy of California Department of Fish and Game) 
established a population in San Francisco Bay (1992). It is reported (but not confirmed) as far north as the estuary of the Columbia River (Draheim et al. 2003). A single specimen of the related species E. japonica, or the Japanese Mitten Crab, was caught by an angler in the Columbia River in 1998 (Jensen and Armstrong 2004). Mitten crabs, which can reach carapace widths of $7.5 \mathrm{~cm}$ (3 in.), are catadromous, that is, they spend most of their adult life in freshwater, returning to the sea only to reproduce. The adults burrow in the banks of rivers and levees, thus posing a direct threat to earthen water control structures.

Fish salvage operations (e.g., the collection of fish at water control structures during drawdowns) and commercial fisheries have been disrupted by the vast number of migrating crabs (Culver and Walter 2001, Wynn et al. 1999).

Commercial San Francisco Bay shrimpers interviewed by Rudnick and Resh (2002) claim that up to 40 percent of their catch is killed or damaged by crabs. The crab's sharp spines, claws, and legs puncture the shrimp during towing or retrieval. Significant time was also lost cleaning and repairing torn nets. Concern for human health has been raised because this species harbors the parasitic Chinese lung fluke, although no flukes have been detected in U.S. crab populations (NOAA 2001).

U.S. populations of the mitten crab are most closely related to German populations and are thought to have entered the United States via ballast water making introduction to the United States, an example of a stepping stone invasion (Hanfling et al. 2002). There is still the possibility they may have been deliberately introduced, since the crabs are considered a delicacy by many. Illegal to import since 1989, shipments continue to be interdicted (USFWS 2003).

Much of what is known about the mitten crab has previously been summarized by Veldhuizen and Stanish (2002). Adults migrate from freshwater into estuarine waters during the fall or winter where they mate and over-winter. As in most crabs, the female carries the eggs under the abdomen until they are ready to hatch in spring (Anger 1991). The larvae are able to develop in a wide range of salinities with optimum growth varying upon the larval stage. Early stage larvae (zoea) grow best in relatively high salinities ( $\sim 25 \mathrm{ppt})$, while late stage or megalopal larvae grow best between $15 \mathrm{ppt}$ and $25 \mathrm{ppt}$. Megalopal stage larvae settle out of the plankton in late spring to early summer as they metamorphose into early juvenile stages. They then begin to migrate towards the fresher portions of the estuary. Veldhuizen and Stanish (2002) indicated that juveniles prefer to burrow in tidal areas, although they also burrow in non-tidal regions. They are most abundant along steep clay banks just below the root zone of adjacent vegetation. Further migration upstream occurs during the following winter. The adults, which can live up to five years, are omnivorous, although stable isotope studies by Rudnick and Resh (2003) suggest benthic invertebrates are their most important food item. Mitten crab populations undergo large fluctuations in abundance over time. At least five peaks in abundance have occurred in Germany: 1930-1939, 1953-1960, 1969-1975, 1979-1983, and 1993present, and appear to be related to water temperature, freshwater flow, and impacts to prey species resulting from pollution events (Aquatic Nuisance 
Species Task Force 2002). In San Francisco Bay, populations were abundant immediately after introduction but have been difficult to find during recent surveys of the San Joaquin River basin and Suisun Marsh (May and Brown 2001).

A draft national management plan for E. sinensis promulgated by the Aquatic Invasive Species Task Force (2002) focuses primarily upon early detection. A variety of potential control methods have been suggested including active trawling for adults during the reproductive phase. Culver and Walter (2001) claim some success with a passive system that traps the crabs as they migrate into the estuary. For further information on the Chinese Mitten Crab, see the Aquatic Nuisance Species Research Program (ANSRP) website at http://el.erdc.usace. army.mil/ansrp/eriocheir sinensis.htm.

Perna viridis, the Asian green mussel, is native to the tropical Indo-pacific with populations distributed between the South China Sea and the Persian Gulf (Figure 3). It first appeared in the western hemisphere in Trinidad in 1990 (Agard et al. 1992), then in Venezuela (Rylander et al. 1996) and in

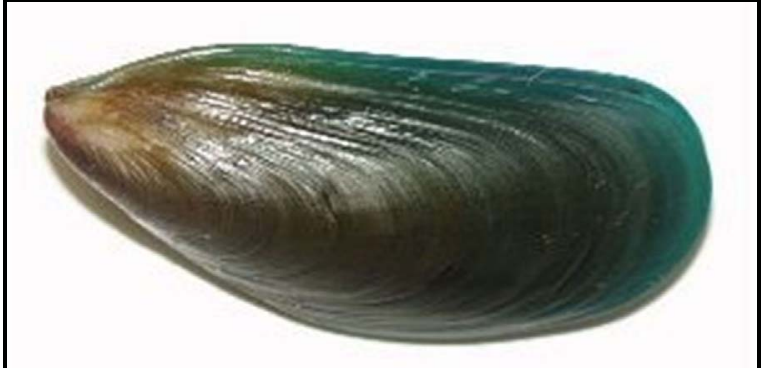

Figure 3. The Green Mussel, Perna viridis (image courtesy of USGS) Tampa Bay, Florida in 1999 (Benson et al. 2003, Ingrao et al. 2001). At present, it is distributed from Tampa Bay to Charlotte Harbor, Florida and has been reported from Kingston Harbor, Jamaica (Buddo et al. 2003).

Like the freshwater zebra mussel (Dreissena polymorpha), the green mussel attaches by a byssal thread to any hard structure. Its initial discovery in Tampa Bay was due in large part to the fact that it was clogging water intake pipes at local power plaints (USGS 2001). It is also known to foul navigation buoys and ship hulls, interfere with shellfish culture, and displace local fauna. They may also harbor microalgal species that produce toxic shellfish poisoning (Buddo et al. 2003).

Introduction to the Caribbean is believed to have been from ballast water and subsequent dispersal either by ballast water or the prevailing currents. There is no way to confirm the mode of introduction. Genetic studies to identify likely source populations have not been conducted. It is assumed that it will continue to spread until it reaches its thermal limits. Green mussels can tolerate temperatures from $10-30{ }^{\circ} \mathrm{C}$, but do best between $26^{\circ}$ and $32^{\circ} \mathrm{C}$ (Segnini de Bravo et al. 1998). They tolerate salinities as low as $16 \mathrm{ppt}$ with salinities of 27-33 ppt being optimal.

The green mussel is a filter feeder and can attain a length of $150 \mathrm{~mm}(\sim 6 \mathrm{in}$.). It grows quickly and reaches sexual maturity within 2-3 months. It is dispersed by veliger larvae that spend 2-3 weeks in the plankton, then settle out on any suitable hard surface including bridges, wharfs, piers, pilings, mangrove roots, 
logs, metal drums, sea grass blades, and rubber tires (USGS 2001, Baker et al. 2003, Buddo et al. 2003). They are cultivated in the Pacific as food, but are inedible in Tampa Bay due to local water quality conditions. The mussel is presently expanding its habitat distribution within the bay. Not considered an immediate threat to local oyster beds when first detected, up to 90 percent of adult Crassostrea virginica on invaded commercial beds have since died (Baker et al. 2003). Crested oyster (Ostrea edulis) populations do not seem to be affected yet. The authors suggested that red mangrove (Rhizophora mangle) roots may provide a refuge for oysters since they were not fouled by the mussels. This is in contrast to Buddo et al. (2003) who reported the highest densities of mussels $\left(\sim 1,300\right.$ animals $\left./ \mathrm{m}^{2}\right)$ to be found on mangrove roots.

Perna perna, the brown mussel, is also a potential threat (Figure 4). A native of South Africa, it has successfully invaded South America from Uruguay to the Caribbean (Gulf States Marine Commission 2003). It was first detected in the United States on a Port Aransas, Texas jetty in 1993 and is now distributed from Freeport, Texas to Veracruz, Mexico (Hicks and Tunnel 1993, 1995). Slightly smaller than its congener, the brown mussel shares most of its biological

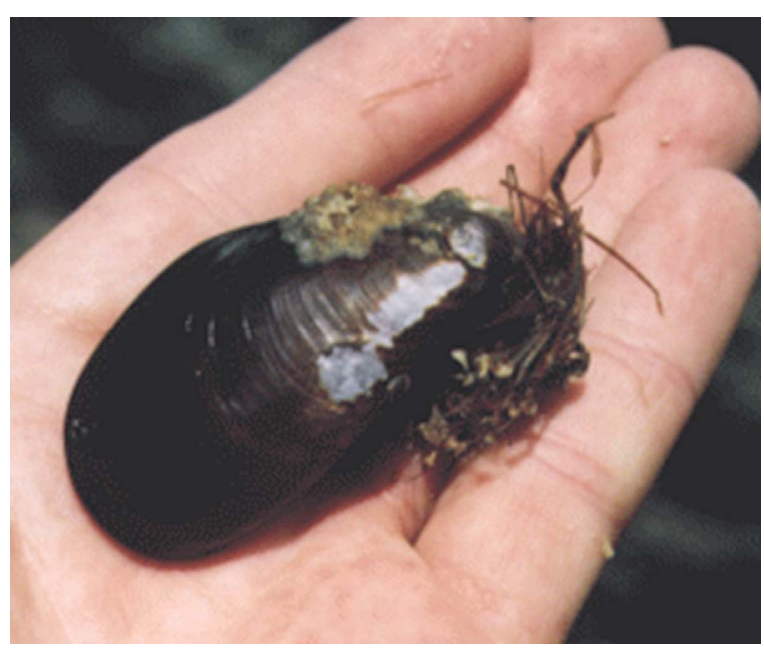

Figure 4. The Brown Mussel, Perna perna (image courtesy of Gulf States Marine Fisheries Commission) characteristics. It reaches a maximum size of $120 \mathrm{~mm}$. The Brown mussel has planktonic larvae that reside in the water column for up to three weeks and settle on hard surfaces. The adult is a filter feeder, probably introduced by ballast water. The mussel tolerates salinities of $15-50 \mathrm{ppt}$ and temperatures from $10-30{ }^{\circ} \mathrm{C}$ (Gulf States Marine Commission 2003).

The Brown mussel is a common mariculture species that grows rapidly and can reach harvestable size in 6-7 months (Hicks et al. 2003). Like the green mussel, it can foul virtually any hard surface, and it poses a threat similar to that of the green mussel. It has been reported from jetties, navigational buoys, and oil platforms as well as natural hard bottom substrates (Hicks and Tunnell 1995).

Mytilus galloprovincialis, the Mediterranean blue mussel, has been introduced to both west coast and Hawaiian waters (Eldridge and Evenhuis 2002, Nonindigenous Aquatic Species Database 2004). As its name implies, the blue mussel's native range is the Mediterranean. Currently, it is found worldwide in temperate seas. Nominated as one of the "top 100 world's worst invaders," it displaces native mussels (including the P. perna in South Africa) (Global Invasive Species Database 2004). In the continental United States, its range extends from Coos Bay, Oregon to San Diego, California. In Hawaii, it is 
reported primarily from Pearl Harbor. Like the green and brown mussels, M. galloprovincialis is a member of the family Mytilidae and shares many of the biological characteristics of those species. The Mediterranean blue mussel can be difficult to identify since it is closely related to native species such as $M$. trossulus, M. californianus, and M. edulis. Geller (1999) has suggested that this physical similarity delayed recognition that it was replacing native M. trossulus populations in Southern California after its initial introduction.

\section{Potential Threats to Habitat Restoration}

As described in the introduction, the Amur River Corbula clam Pomatocorbula amurensis is a native of Chinese, Japanese, and Korean waters, and has had a significant impact on the ecology of San Francisco Bay. It inhabits both intertidal and subtidal mud and sand, tolerates salinities of 1-33 ppt, and temperatures of $1-28^{\circ} \mathrm{C}$ (Cohen and Carlton 1995). It feeds on bacterioplankton and phytoplankton and can digest nauplii larvae of some copepods (Kimmerer et al. 1994, Werner and Hollibaugh 1993). Although it is presently limited to San Francisco Bay, it is dispersed by planktonic larvae and therefore has the potential for widespread distribution. This species may interfere with the natural recolonization of dredged material deposits or sediments employed in beneficial use projects.

Musculista senhousia, the Asian date mussel (Figure 5), is native to intertidal and subtidal sediments from Siberia to the Red Sea and is now found in Australia, New Zealand, the eastern Mediterranean, and southern France (Crooks, 1996 and references therein). Probably introduced into the United States in 1924 during introduction of Japanese oysters to Samish Bay, Washington, it has since spread as far as Southern California. Ballast water is assumed to be the major pathway for introduction.

The date mussel grows to about 32 $\mathrm{mm}$ total length, most of which $(25 \mathrm{~mm})$ occurs in the first of its two-year life span (Crooks 1998, Mistri 2002). It produces planktonic larvae that can remain in the water column as long as 55 days. The larvae preferentially settle out on muddy or sandy substrates. This species forms dense beds that significantly alter nearby sediments and native benthic assemblages (Crooks

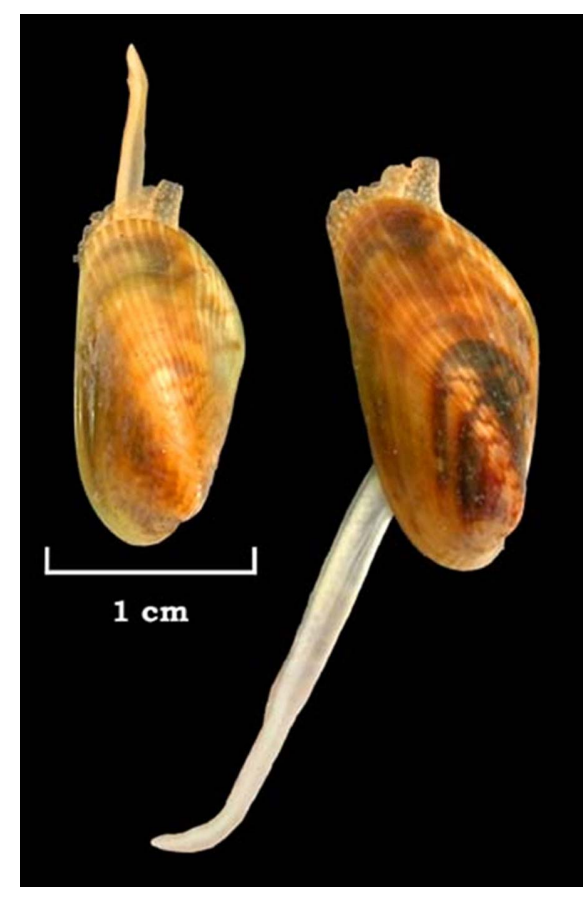

Figure 5. The Asian Date Mussel Musculista senhousia (image courtesy of California Academy of Sciences) 
1998, Crooks and Khim 1999). Mussel bed sediments are generally finer and have higher organic content than those outside the bed. Infaunal abundance and diversity are enhanced within the beds; however, a number of species normally dominant in these habitats appear to be inhibited. This includes many species with planktonic development such as the spionid polychaete Pseudopolydora paucibranchiata. A few species are found in enhanced abundance within the beds including the tanaid Leptochelia dubia and the snail Barleeia subtenuis. Experiments have shown that the changes brought about by the date mussel are the result of the physical presence of the shells rather than a biologically induced response. Populations are highly variable with densities ranging from negligible to nearly $9,000 / \mathrm{m}^{2}$ and annual mortality as high as 96 percent within any given year. A variety of native animals have learned to feed upon $M$. senhousia including several species of shorebirds and bottom-feeding fish (Crooks 2002) as well as the previously mentioned snail $P$. festiva (Reustch 1998). Since much of dredged material is comprised of soft sediments, this species may interfere with the natural recolonization of dredged material deposits or sediments employed in beneficial use projects. Transplantation success of seagrass restoration projects may also be reduced in infested areas. Reutsch and Williams (1998) reported that rhizome elongation (a major mechanism for seagrass bed growth) is reduced by 40 percent in the presence of $M$. senhousia.

$\quad$ Carcinus
maenas, the
European green
crab (Figure 6), is
native to northern
Europe and inhabits
a wide range of
habitats in sheltered
areas including
rocky intertidal,
unvegetated
intertidal, subtidal
mud and sand,
saltmarshes, and
seagrasses. They
are usually a dark
green color and
reach sizes up to
8 cm (carapace
width). They

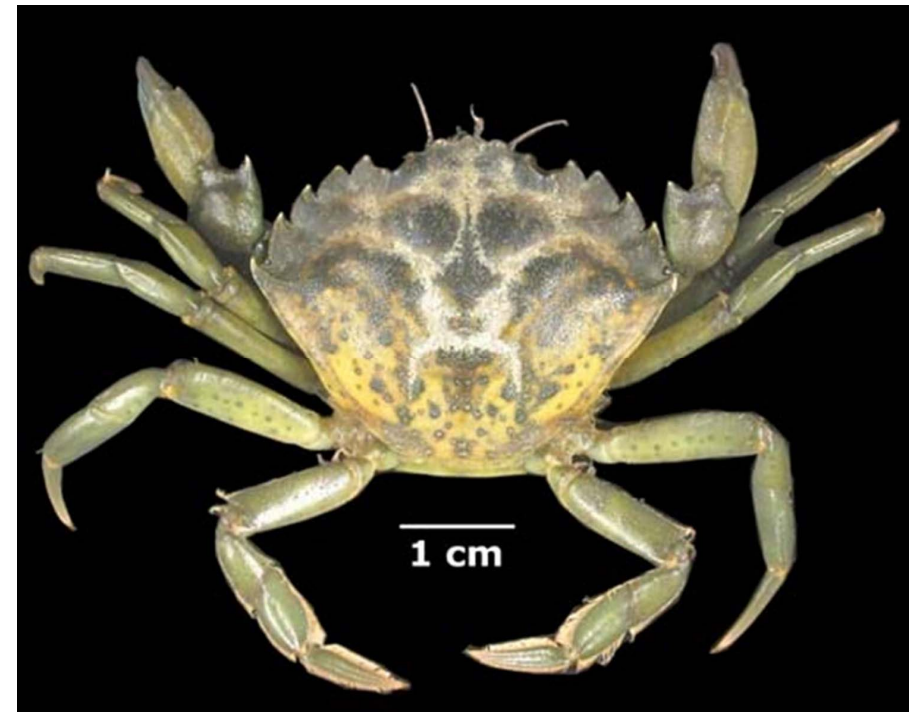

Figure 6. The European Green Crab, Carcinus maenas (image courtesy of California Academy of Sciences)

tolerate a wide range of salinities and temperatures, but prefer mesohaline to polyhaline salinities $(10-30 \mathrm{ppt})$ and temperatures between $3{ }^{\circ} \mathrm{C}$ and $26{ }^{\circ} \mathrm{C}$ (Groshloz and Ruiz 2002). The green crab is now found in South Africa, Japan, and Australia. It was introduced to the east coast of North America sometime in the 1800's (Scattergood 1952) and has since invaded the west coast. First detected in San Francisco Bay (Cohen et al. 1995) in 1989, it was soon found in other California estuaries (Grosholz and Ruiz 1995). It has been sighted as far north as Oregon (Miller 1996) and Vancouver Island, Canada (Yamada et al. 2001). Gray Hitchcock et al. (2003) predict that it could eventually move into 
Alaskan waters. Introduction may have occurred by one or more different mechanisms including ballast water, dry ballast, packing materials for oyster shipments, live bait, etc. (Cohen et al. 1995). Genetic studies have shown that invasion of the Pacific coast was from east coast populations (Bagley and Geller 1999). Secondary expansion along the west coast is attributed to transport of the planktonic larvae by oceanic currents (Yamada et al. 2001).

The green crab has a 6-year life span in Maine, but appears to survive only 3-4 years in Oregon (Yamada et al. 2001). This shorter life span may be due to a much higher growth rate. Females are capable of producing several clutches of eggs a year. The planktonic larvae take approximately 90 days to develop and metamorphose into benthic juveniles. In their native range, juveniles prefer to settle out in mussel beds, eelgrass beds, and patches of filamentous algae (Moksnes 2002). Older juveniles then actively migrate to mussel beds. Beukema (1991) reported that in the Wadden Sea, green crab abundance is higher after mild, rather than severe (cold), winters.

The green crab is omnivorous, feeding on detritus, algae, snails, bivalves, annelids, crustaceans, and other benthic organisms (Ropes 1968). The diet changes as the crabs age. Early stage juveniles feed primarily on detritus, then shift to infauna as they get older (Pihl 1985). Adults appear to prefer to prey on bivalves. In its native range, the green crab actively seeks out the blue mussel Mytilus edulis and the cockle Cerastoderma edule, but will also feed on both native and introduced oysters (Mascaro and Seed 2000a, 2000b). Crabs are selective in the size of animals on which they feed, and prey on successively larger prey as they increase in size (Mascaro and Seed 2000a, 2000b). SanchezSalazar et al. (1987a, 1987b) have shown that Welsh populations of C. maenas control the size, abundance, and intertidal distribution of the cockle C. edule. The crab, which moves in and out with the tides, feeds preferentially on small animals. Cockles greater than $15 \mathrm{~mm}$ long are relatively free from crab predation, but are more likely to be taken by shorebirds if in shallow water. Thus cockle populations in the low intertidal, where the crabs are the dominant predator, tend to be comprised of a few small animals and somewhat larger ones, while those of the high intertidal, where shorebirds are the dominant predator, are made up almost entirely of small animals. Jensen and Jensen (1985) have reported similar relations between cockle size and green crab predation in the Danish Wadden Sea. Predation by C. maenas has significant impacts on both natural and cultured bivalve populations in the United States and worldwide. Declines in soft clams (Mya arenaria) in New England (Glude 1955), Nutricola spp. in Central California (Grasholz et al. 2000), and the venerid clam Katelysia scalarum in Tasmania (Walton et al. 2002, Ross et al. 2004) are all attributed to C. maenas. McDonald et al. (2001) have shown that $C$. maenas is capable of outcompeting the Dungeness crab Cancer magister for food, however their habitats generally do not overlap. The green crab can also induce morphological and behavioral changes in its prey. The snail Littorina obtusata responds to crab tissue extracts by developing thicker shells (Smith and Trussell 1999) and soft clams respond by burrowing deeper into the sediment when crabs are detected (Whitlow 1999, Whitlow and Dochtermann 2000). 
In turn, green crabs can be affected by competition or predation from other species. McDonald et al. (2001b) have shown that although habitat distributions of $C$. maenas and the native crabs Cancer productus and $C$. antennarius could potentially overlap in Northwest estuaries, in practice they seldom do. The green crab tends to be limited to low-energy soft bottoms and especially marsh habitats (including stands of the invasive Spartina alterniflora). As previously mentioned, this distribution is due to predation by native species on the green crab (Hunt and Yamada 2003). De Rivera et al. (2003) have described a similar distribution pattern on the east coast for the green crab and the native blue crab Callinectes sapidus. Jensen et al. (2002) have shown experimentally that in Puget Sound, although C. maenas outcompetes the native grapsid crab Hemigrapsus oregonensis for food, it is precluded by this species from one of its favorite habitats, beneath rocks. They also show, ironically enough, that green crab populations on the east coast may now be outcompeted by another invasive crab, the grapsid H. sanguineus (Cassanova 2001, Jensen et al. 2002).

An obvious concern about $C$. maenas from the point of view of USACE is that this species could interfere with attempts to restore shellfish habitat. Control measures have generally been unsuccessful and limited to trapping. Recent interest in biocontrol by introducing the rhizocephalan barnacle Sacculina carcini, a parasitic castrator, to the west coast has dimmed since it was discovered that this parasite can also infect native crabs including Hemigrapsus oregonensis, H. nudus, Pachygrapsus crassipes, and commercially important C. magister (Goddard 2001). Torchlin et al. (1996) reported that a native egg predator of $H$. oregonensis, the nemertean Carcinonemertes epialti is infecting green crabs and may act to naturally control this species.

Rapana venosa, the veined rapa whelk (Figure 7), is native to the Sea of Japan and was first detected in Chesapeake Bay in 1998 (Mann and Harding 2000a). Already known as an invasive species in the Black, Adriatic, and Aegean Seas, it is thought to have entered via ballast water. Preferring hard sandy bottoms with salinities of 18-28 ppt, it can reach a total length of $150 \mathrm{~mm}$. In Chesapeake Bay, the whelk mates between October and July and lays egg mats between May and August (Westcott et al. 2001). Individual animals lay mats of 50-300 egg cases, each with 200-400 eggs per case (Ware et al. 2001). The eggs require 14-45 days to incubate, yielding veliger larvae that spend up to 78 days in the plankton before settling out (Mann and Harding 2000b, Harding and Mann 2000). The young grow quickly reaching lengths of $40-50 \mathrm{~mm}$ within 5 months and more than $60 \mathrm{~mm}$ by the end of their first year (Harding and Mann 2001). The juveniles feed primarily upon barnacles, mussels, and newly settled and very young oysters. At approximately $70 \mathrm{~mm}$ in length, the whelks migrate into deeper water and begin to feed on Mya arenaria and Mercenaria mercenaria. In addition, whelks may feed on the razor clam Ensis directu, and the false angelwing Cyrtopleura costata (Harding and Mann 1999). 


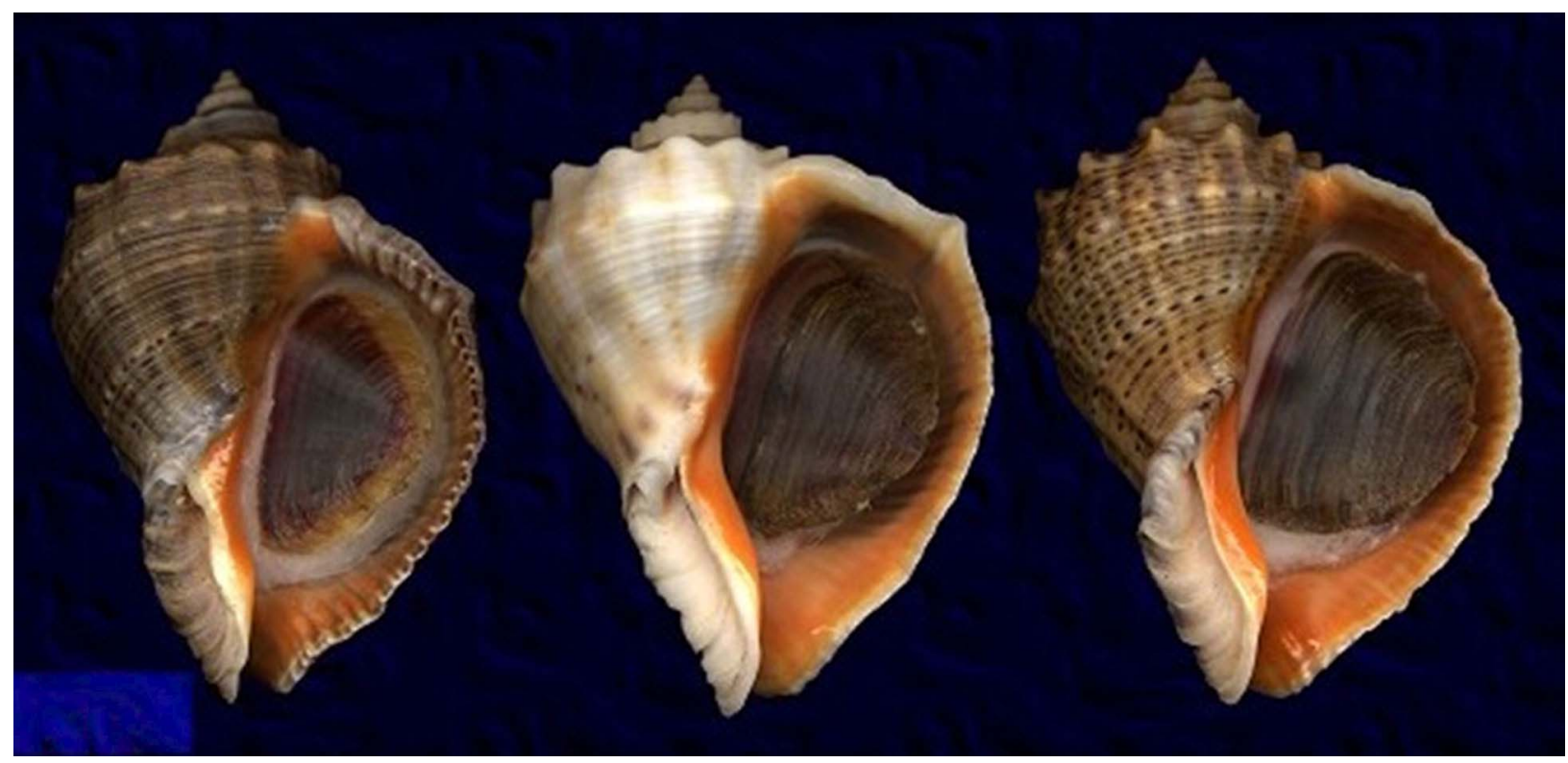

Figure 7. The Veined Rapa Whelk, Rapana venosa (image courtesy of the Jacksonville (FL) Shell Club)

Salinity appears to be a major factor determining the distribution of Rapana, particularly during its larval and juvenile stages. O'Neill (2001) reported that larvae begin to suffer mortality during 48-hr exposures to salinities below 15 ppt and cannot survive exposure at 10 ppt. The North American distribution of this species is limited to portions of Chesapeake Bay. Mann and Harding (2003) predict that bay currents will spread it to most of the lower western shore of the bay and even in the absence of separate introductions, it is likely to spread from Cape Cod to Cape Hatteras.

This species could potentially affect USACE efforts to restore shellfish habitat in Chesapeake Bay and elsewhere. There is some evidence indicating that predation by the blue crab may assist in controlling this species. Blue crabs prey on young whelk up to $55 \mathrm{~mm}$ in length and especially those less than $35 \mathrm{~mm}$ long (Harding 2003). Recent control measures have included offering a bounty for whelks ( $\$ 5$ live, $\$ 2$ dead, and/or a free T-Shirt). Another novel approach to control is the encouragement of local restaurants to develop recipes incorporating this species (http://www.vims.edu/mollsuc/reseach/ rapaw/rapup.htm).

The green porcelain crab, Petrolisthes armatus (Figure 8) is a South American and Caribbean filter feeding species that until recently was found occasionally in the Gulf of Mexico. Sometime after 1977, it was noticed in increasing numbers and further north (Knott et al. 1999). It is now distributed as far north as Georgia and South Carolina in rocky intertidal and tidal creek oyster bar habitats. In the Gulf of Mexico its habitat distribution includes sheltered areas of lower estuaries on oyster reefs, shell bottoms, and barnacle-fouled pilings and jetties (Felder 1973). Lohrer (2001) has reported concentrations of $10,000 / \mathrm{m}^{2}$ from South Carolina salt marshes. At this point, it is unclear whether this species is simply undergoing a natural range expansion or has been 
inadvertently introduced outside its normal range. Hartman et al. (2001) suggest that the abundance of $P$. armatus may indirectly damage oysters by providing an alternative prey for predators of xanthid crabs. Xanthids feed on oyster spat, therefore, anything that reduces predation pressure upon them may lead to increased predation on spat. Field experiments by Hollebone and Hay (2003) support this conclusion.

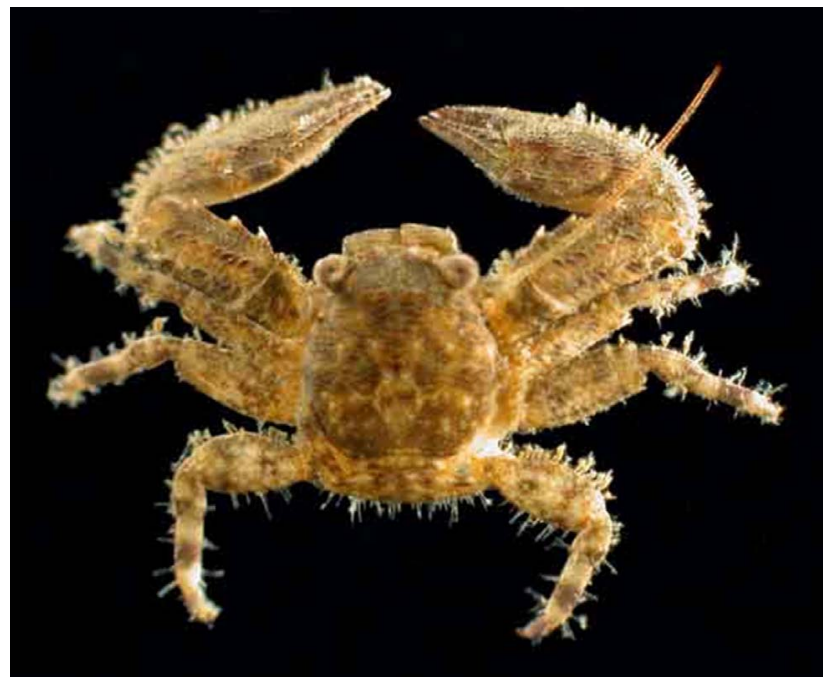

Figure 8. The Green Porcelain Crab, Petrolisthes armatus (image courtesy of Southeast Regional Taxonomic Center)

\section{Sphaeroma}

quoyanum is a marine isopod similar in size and shape to the common garden pillbug (Figure 9). Native to Australasia, it is a wood-boring species most likely introduced on the hulls of ships during the California gold rush. It is presently distributed from San Diego Bay, California to Coos Bay, Oregon (Talley

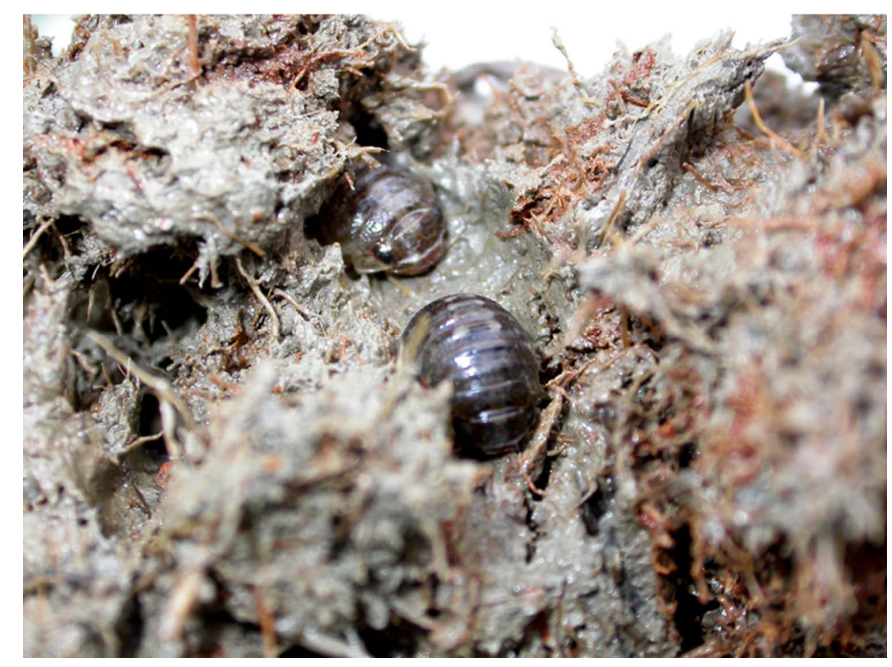

Figure 9. Sphaeroma quoyanum et al. 2001). Sphaeroma burrows into a variety of substrates including wood, soft rock, and salt marsh peat. It prefers the salt marsh peat of Salicornia spp. dominated marshes and is found predominately high in the intertidal zone on bay-front rather than creek edge marsh banks. It is most common on vertical and undercut banks where it forms horizontal burrows averaging $2-\mathrm{cm}$ long and $0.7 \mathrm{~cm}$ wide. These generally intersect other burrows producing a "swisscheese" like texture that significantly weakens the bank eventually resulting in undercutting, collapse of the marsh edge, and severe erosion (Figure 10). 


$\quad$ Sphaeroma
appears to be a filter
feeder; therefore, it
does not actually
consume the peat
during burrowing
(Talley et al. 2001).
It can achieve
densities as high as
$8,000 / \mathrm{m}^{2}$. This
species clearly has
the potential to
interfere with the
long-term success of
USACE wetland
restoration efforts,
however, it may be

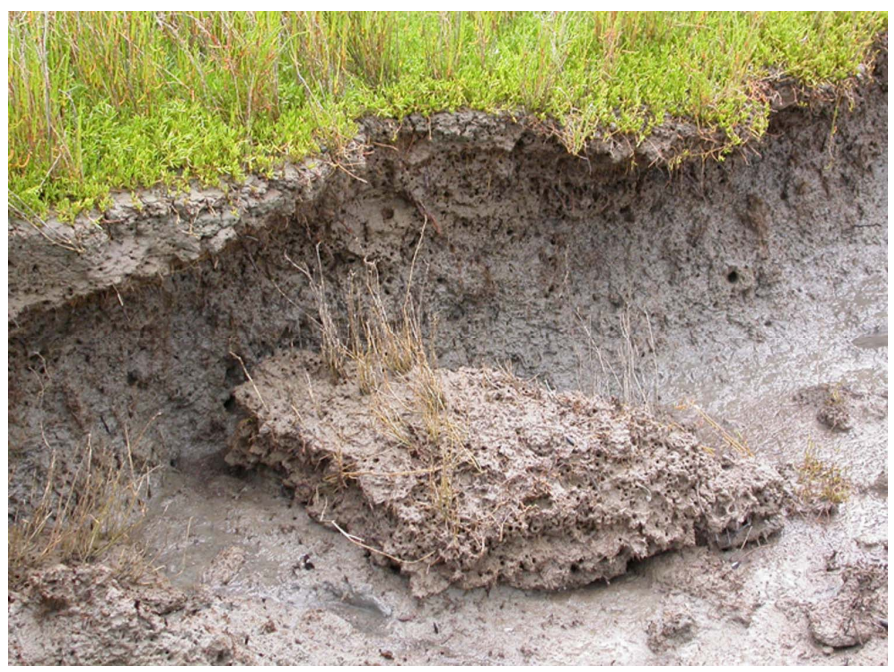

Figure 10. Marsh erosion due to burrowing possible to limits its effects. Pointing out that burrow densities are vastly greater (7-2,200 fold) on vertical rather than sloping banks, Talley et al. (2001) suggest that incorporating sloped banks into salt marsh restoration projects may prevent erosion associated with this species.

Sphaeroma terebrans, a close relative and also a wood-borer, is native to the Indian Ocean. Like S. quoyanum, it is likely to have been introduced on the hulls of wooden ships. Its date of introduction is uncertain, but is presently found from Brazil to South Carolina and from Liberia to the Congo (Carlton and Ruckelshaus 1997). It burrows into hard substrates including hard packed sand, and decaying or living wood. Rehm and Humm (1972) report that the isopod burrows into the prop roots of red mangrove (Rhizophora mangle) in southwestern Florida, weakening and ultimately destroying them. This damages the individual mangrove plant and leads to undercutting and erosion of exposed sediments. Simberloff et al. (1978) suggested that root boring might be beneficial to mangroves in the sense that it stimulated branching. Ribi (1981) and Perry and Brusca (1989) have refuted this and documented substantial declines in growth of infected roots. This species poses potential difficulties for mangrove restoration in the southeast Atlantic.

Phylloriza punctata, the Australian Jellyfish (Figure 11), has recently been found in large numbers in the Northern Gulf of Mexico. Adults average $35 \mathrm{~cm}$ (bell width), can reach $65 \mathrm{~cm}$, and weigh in excess of $20 \mathrm{~kg}$ (wet weight) apiece (Graham et al. 2001). Native to the tropical western Pacific, it has already invaded Hawaii, Southern California, the eastern Mediterranean, and the Caribbean. In its native range Phylloriza contains symbiotic algae (zooanthellae) that subsidize its energy requirements. Specimens collected from the Gulf of Mexico lack these symbionts and must obtain all of their food requirements by grazing on plankton. Reports of swarms with more than 500,000 animals in a $150-\mathrm{km}^{2}$ area suggest that intense predation could reduce the abundances of both small zooplankton (e.g., copepods) and the eggs, larvae, and juveniles of many fish species (Graham et al. 2003). 
Large masses of this species pose both a threat to fisheries and a severe inconvenience to the shrimp and fishing industries. The jellyfish clog trawl nets resulting in increased time to separate the catch and clean the nets. The primary concern in relation to this species is its potential to disrupt USACE fisheries restoration and enhancement projects.

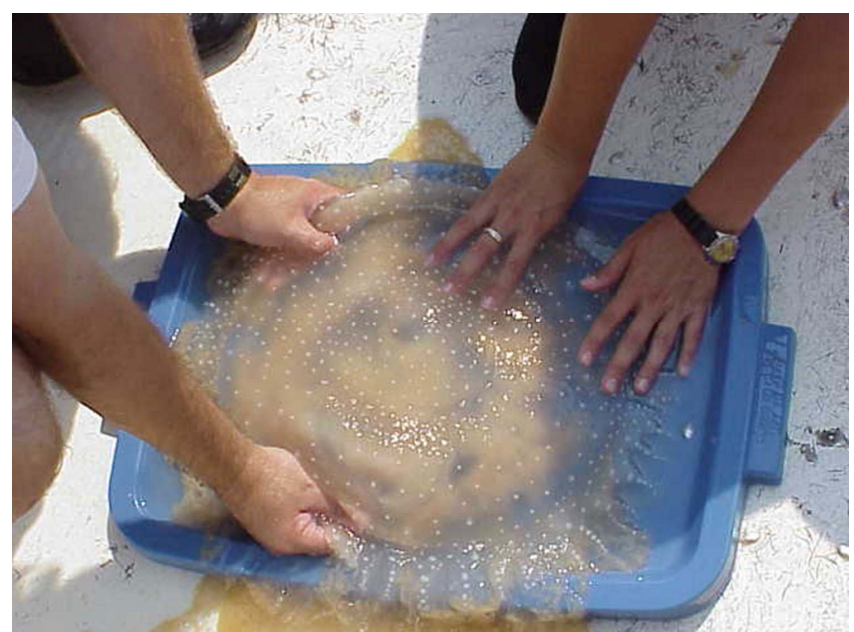

Figure 11. The Australian Jellyfish, Phylloriza punctata (image courtesy of Dauphin Island Sea Lab)

Other jellyfish that have invaded U.S. waters include the hydrozoans Maeotias inexpectata and Blackfordia virginica. Both are native to the Black Sea and have been found in estuarine waters of San Francisco Bay (Mills and Somer 1995). Both species have established populations near the Petaluma and Napa Rivers (11-20 ppt) at least since 1992. Only male specimens of $M$. inexpectata have been collected, making it likely that they are reproducing by budding. Concerns raised about these species center on the European experience with the invasion of the Black Sea by the North American ctenophore Mnemiopsis leidyi. Mnemiopsis successfully invaded the Black Sea sometime in the 1980's, and has been linked to sharp declines in zooplankton and anchovy and other fish abundances (Kideys 2003). It has since invaded the Seas of Azov and Marmara and the Caspian Sea (Shiganova et al. 2001). It has recently been argued that the predatory impacts of this ctenophore, while severe, were only one in a series of stressors that created dramatic declines in Black Sea ecosystems (Bilio and Niermann 2004).

\section{Venomous Species}

While not a threat to infrastructure or habitat restoration, the lionfish Pterois volitans (Figure 12) is a potential problem for USACE divers. Native to the Indian Ocean and western Pacific coral reefs, the lionfish is a favorite aquarium fish because of colorful appearance. Unfortunately, it is also venomous. Lionfish first began being noticed in Florida waters in 1994 and may have been introduced when a private aquarium was demolished in the Miami area during Hurricane Andrew in 1992 (Gare and Whitfield 2003). It may also have been introduced either in separate aquarium spills or by ballast water (Whitfield et al. 2002). It lives on hard bottoms, coral reefs, and artificial substrates from 26 to $79 \mathrm{~m}$ deep and is often associated with ledges and crevices. 
It is presently found from Florida to Cape Hatteras, North Carolina. Although it is unlikely that breeding populations will be established further north than the Carolinas, juveniles have been reported as far north as Long Island, New York during the summer (Gare and Whitfield 2003). Lionfish are ambush predators that fed mostly upon small fish, crabs, and shrimp. Their effect on local ecosystems has not been assessed.

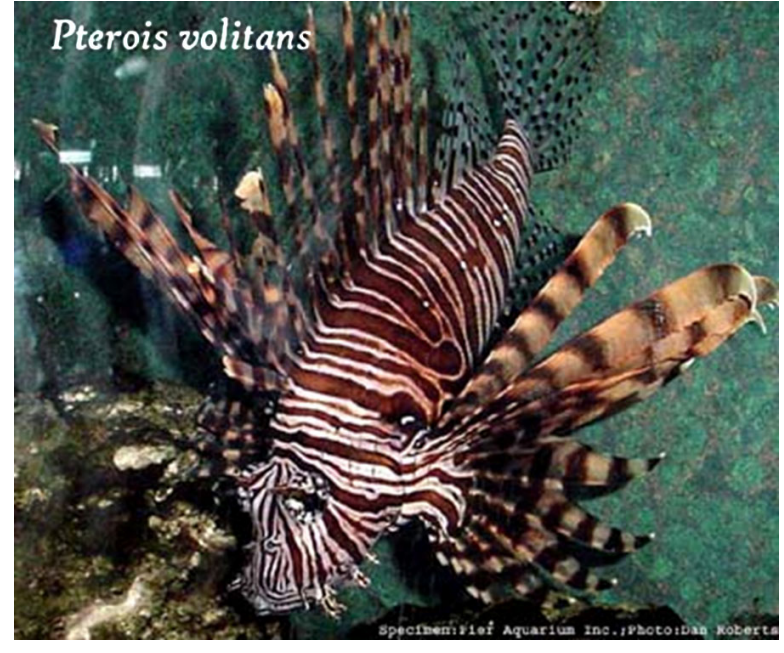

Figure 12. The Lionfish, Pterois volitans (image courtesy of Florida Fish and Wildlife Conservation Commission)

\section{Potential Future Threats}

There are a number of species that have invaded coastal habitats elsewhere that could pose a problem for the USACE if or when they arrive in U.S. waters. One of the chief of these is the giant fanworm, the sabellid polychaete Sabella spallanzanii. Native to the Mediterranean Sea and the eastern Atlantic from Northern France to Morocco, it has established populations in the Azores, Brazil, Java, and Australia (CRIMP 2001). Introduction to Australia is believed to have been part of the fouling community on ships' hulls, although transport of the larvae by ballast water is also possible. Genetic evidence indicates that Australian populations are all derived from a single Mediterranean source (Ward and Andrew 1996). Preferring sheltered areas such as harbors, the worms form tube mats at depths ranging from 1 to $30 \mathrm{~m}$. Tube mats can become large enough to be mistaken as seagrass beds in aerial photographs (Clapin and Evans 1995). Individual tubes are approximately $40 \mathrm{~cm}$ long, and the fan of feeding tentacles can extend another 10-15 cm. Filter-feeding by the worms decreases plankton concentrations underneath the tube canopy and strongly affects settlement of other species (Holloway and Keough 2002). The worms attach to virtually any submerged hard surface including pilings, navigational buoys, pontoons, shell fragments, dead seagrass rhizomes, and solitary tunicates (Clapin and Evans 1995). They can also successfully settle into soft sediments. As with the green and brown mussels, giant fanworms may pose a threat to water control structures if they become established in the United States.

The Santo Domingo false mussel Mytilopsis sallei, closely related to the freshwater zebra mussel (Marelli and Gray 1985), shares many of its characteristics including the potential to create serious fouling problems. A native of Central America, M. sallei has invaded the Indian Ocean and Australia (Hewitt 2002). There is also an unidentified species of Mytilopsis, which poses a 
similar threat. Bax et al. (2002) have described how this species invaded Darwin Harbor, Australia and was subsequently eradicated (See Chapter 7 for how this was accomplished).

The Northern Pacific seastar Asterias amurensis has been identified as an invasive species in Australia and has the potential to reach U.S. waters. Native to the northern coast of China, Korea, Russia, and Japan, it is most likely to be introduced as larvae in ballast water (Department of Fisheries, Government of Western Australia 2004). The adults reach sizes of 40-50 cm (diameter) and live up to five years. They live in sheltered subtidal areas to a depth of $200 \mathrm{~m}$ on mud, sand, or pebble substrates, produce planktonic larvae, and feed heavily on shellfish. Although their native range of water temperatures is $7-10{ }^{\circ} \mathrm{C}$, they have adapted to temperatures as high as $20^{\circ} \mathrm{C}$. Larvae of Tasmanian populations have an optimal temperature range of $8-16.5^{\circ} \mathrm{C}$ (Sutton and Bruce 1996). Larvae grow well at 28-32 ppt but cannot survive exposure to salinities of 9 ppt or less. Byrne et al. (1997) have examined its reproduction in Tasmanian waters and report breeding from April to June followed by major spawning in July to October.

\section{Other Species That Merit Consideration}

In addition to species that directly interfere with USACE activities, there are a number of others that have recently gained national or local recognition that may be of interest to the Corps of Engineers community. The first of these is the Japanese shore crab Hemigrapsus sanguineus, a native of Japanese, Korean, and Chinese waters; it has invaded rocky intertidal habitats from North Carolina to New Hampshire and possibly Maine. First collected in New Jersey in 1998 (Williams and McDermott 1990), it was probably introduced in ballast water. The crabs average $30 \mathrm{~mm}$ (carapace width) and have been reported at densities as high as $120 / \mathrm{m}^{2}$ (Lohrer and Whitlach 1997, O'Connor 2001). Reproducing in spring, the female releases planktonic larvae between June and September. Larvae take 16 days to develop and settle at temperatures of $25{ }^{\circ} \mathrm{C}$ and up to 55 days at $15^{\circ} \mathrm{C}$ (Park 1999, Epifaunio et al. 1990). Megalopal stage larvae settle an average of 25 days after hatching when they metamorphosize into benthic juveniles. The crabs feed primarily upon brown and red algae, barnacles, and blue mussels (Mytilus edulis), although they also prey on gastropods and polychaetes (Lohrer and Whitlach 1997, Bordeau and O'Connor 1999). They appear to outcompete many native crab species and may be displacing green crabs (C. maenas) in some habitats (O’Connor 2001).

The white lace bryozoan Membranipora mebrancaea is a low growing, colonial species with a worldwide distribution. It fouls any hard surface in oceanic salinities and has long been known to be destructive to kelp on the west coast. Kelp blades can become so encrusted with Membranipora (up to 65 percent cover) they are readily torn off by wave action or seriously damaged by fish feeding on the bryozoan colonies (Dixon et al. 1981). This species has recently invaded the Northeast (New York to Maine), where it is now the dominant fouling animal on laminarian kelp (Berman et al. 1992, Lamber et al. 
1992). It is important to remember that the closely related M. tenuis, a common fouling organism in estuarine habitats, is native and not a threat.

A number of tunicates (sea squirts) have also recently invaded subtidal rocky habitats in New England. The most abundant are Botrylloides diegensis, a Californian species, and Styela clavata, a native of the Philippines (Berman et al. 1992, Osman and Whitlach 1995). Both species are sessile, however Botrylloides is colonial and Styela is solitary in nature. Botrylloides was introduced into a pond at Woods Hole, Massachusetts in 1973, by a biologist (Osman and Whitlach 1995). Styella, with a worldwide distribution including all of the west coast, was first detected in Long Island in 1973. Both species are now established members of the subtidal fouling community and can dominate it during warm years (Stachowicz 2002).

The Japanese false cerith Batillaria attramentaria (= zonalis) is a $35-\mathrm{mm}-$ long snail (maximum length $46 \mathrm{~mm}$ ) introduced to the west coast during importation of Japanese oysters in the 1930's (Morris et al. 1980). It is now found from Elkhorn Slough, California to British Columbia on soft intertidal substrates. It is particularly abundant in water-filled depressions just below mean low water (MLW), where it can reach densities of $7,000 / \mathrm{m}^{2}$. Adults mate between March and June with egg string production peaking in June (Yamada 1982). It feeds on surface algae and generally outcompetes the native mudflat gastropod Cerithea californica (Whitlach and Obrebski 1980; Byers 2000a, $2000 \mathrm{~b}$ ). It is also less sensitive to prolonged low oxygen conditions than the native species (Byers 2000c). Wonham et al. (2003) indicated a positive association of Batillaria with the Asian trematode parasite Cercaria batillariae, and the invasive Asian anemone Diadumene lineata, and the slipper shell Crepidula sp., which live upon its shell. They have shown experimentally that populations of another invasive snail, Nassarius fraterculus, and density of the introduced seagrass Zostera japonica are reduced when Batillaria are excluded.

Another gastropod introduced to the west coast is the eastern mud snail Nassarius (=Ilyanasa) obsoleta. Introduced with American oyster imports during the early $20^{\text {th }}$ century, it is now distributed from San Francisco Bay to British Columbia (Cohen and Carlton 1995). It is most abundant in salt marshes and tidal creeks (sloughs). Displaced in its native range by Littorina littorea (Brenchley and Carlton 1983), it has displaced the native snail C. californica in many California salt marshes (Race 1982).

The common ribbed mussel Geukensia (=Ischadium) demissa of east coast salt marshes also invaded California marshes in the early $20^{\text {th }}$ century and now dominates marsh channel bank habitats (Cohen and Carlton 1995). Its presence may threaten the endangered California Clapper Rail (Rallus longiorostrus obsoletus). Birds feeding on the mussel occasionally get their toes stuck and either drown or lose their toes (Cohen and Carlton 1995).

The Japanese purple varnish clam Nuttalllia obscurata is now established in soft sandy sediments of intertidal areas from northern Washington to British Columbia (Byers 2001). Approximately $40 \mathrm{~mm}$ wide, it has a brown 
periostracum (outer layer of shell) that tends to peel off like old varnish (Mills 2004). The clam gets its name from the purple inner lining of the shell. It was probably introduced into British Columbia in ballast water during the 1980's and is most abundant just below MLW. Dudas et al. (2003) reported that its success is due to their superior burrowing ability, since local crab species feed on it preferentially to native species.

The Caribbean barnacle Chthamalus proteus is the most abundant of the more than 343 introduced marine and estuarine species in Hawaii. The 1-cmwide Chthamalus is native to the Gulf of Mexico, Trinidad, and northeast Brazil and probably was introduced to Hawaii sometime in the 1970's (Southward et al. 1998). It reaches very high densities on pilings and in sheltered rocky intertidal areas where there are few native species (Zabin and Hadfield 2001, Zabin 2003). Two other nonindigenous barnacles, Balanus amphitrite and B. eburneus, have also established populations in Hawaii. Eldridge and Carlton (2002) reported a total of 287 invertebrate and 20 fish species introduced to Hawaii. Seventy-one of the invertebrates are arthropods (barnacles, shrimp, etc.) and fifty-three are mollusks. Most, like Chthamalus, are found predominantly in bays and harbors and were probably introduced in ballast water from the Indo-Pacific (Coles et al. 1999, DeFelice et al. 2001, Godwin and Eldridge 2001). Of the 30 introduced invertebrate species described by DeFelice et al. (2001) in their guide to invasive invertebrates of Hawaii, only four are reported for coral reefs. This seems surprising because of the problem of invasive algae in these habitats. The four species are the serpulid polychaete Salmacina dysteri, the stomatopod crustacean Gonodactylaceus falcatus, the sabellid polychaete Sabellatarte spectabilis, and the Snowflake coral (soft coral) Corijoa riisei. Only the soft coral is considered a serious pest. It overgrows commercially valuable black coral (Antipathes dichotoma and A. grandis), thus threatening a $\$ 30$ million jewelry industry based on the coral (Grigg and Kelley 2002). The relative absence of invasive marine animals on Hawaiian coral reefs is due either to the paucity of opportunities to invade theoretically expected highly diverse communities or to underestimation resulting from the relatively small number of studies conducted (Coles and Eldridge 2002). 


\section{Control and Monitoring}

Effective control of invasive species requires a three-pronged approach: (a) measures to prevent introduction, (b) early detection of new invaders, and (c) elimination of established populations (National Invasive Species Council 2001). Historically, there are only two examples of the successful eradication of an established marine invader reported in the scientific literature. Bax et al. (2002) detected an invasion of the mussel Mytilopsis sp. in Darwin Harbor, Australia. The mussel was found in a set of four boat marinas closed off from the surrounding waters by a set of double-lock gates. The marinas were quarantined and chemically treated with sodium hypochlorite and copper sulphite, then all boats within the marinas were inspected and cleaned. Subsequent monitoring confirmed that the pest had been eradicated. Culver and Kuris $(1999,2000)$ report the elimination of the shell-boring sabellid polychaete Terebrasabella hetrouncintata from Cayucos, California. The polychaete was introduced to a mariculture facility with a shipment of South African abalone and then spread to a nearby intertidal area. Eradication was accomplished by placing screens on the outflow pipes from the facility to prevent further escapes and then removing its preferred native host, the Black turban shell Tegula funebralis, from the immediate area. A total of 1.6 million Tegula had to be removed, but monitoring indicated the control procedures were successful. In both cases conditions were ideal for successful interdiction of the invasion: (a) the invading species was introduced into a small spatial area, and (b) it was detected early in the colonization phase. Unfortunately, these conditions are generally seldom met. Most invasive species, entering the unconfined waters of harbors and estuaries, are able to disperse over a wide area making eradication efforts virtually impossible. It is obviously essential to detect invaders as early in the colonization phase as possible in order to limit the number of animals that need to be removed and the area that must be treated. Detection requires monitoring and to date, the United States is still in the early stages of establishing a nationwide network of monitoring studies. The Smithsonian Institution is coordinating efforts to monitor fouling communities in New England (Rhode Island and New Hampshire), Chesapeake Bay, Florida (Jacksonville), Texas (Corpus Christi and Galveston Bays), California (San Francisco and Mission Bays), Oregon (Coos Bay), Washington (Puget Sound), and Alaska (Kachemak Bay, Dutch Harbor, and Kodiak, Sitka, Unalaska, and Valdez Islands) (For more information see http://invasions.si.edu/Fouling/fs national.htm). Bottom communities are frequently monitored under various programs including the USEPA's Environmental Mapping and Assessment Program (EMAP). In addition, most states now have programs to educate the public and boaters, in 
particular, about invasive species, alerting them to report any unusual or suspicious organisms.

The best hope for effective control of invasive species is preventing them from being introduced. This means that measures need to be in place to deal with both intentional and accidental introductions. In the past, species were intentionally introduced with relatively little thought for potential deleterious results. Randall (1987) lists 21 species of marine and brackish water fish intentionally introduced to Hawaii. All but a few of the introductions failed and none have had catastrophic effects, however, at least five additional species were unintentionally introduced at the same time. The unsuccessful attempt to establish the Marquesan sardine Sardinella marquesensis alone resulted in introduction of the Kanda (Valamugil engeli), the striped goatfish (Upeneus vittatuts), and the goldspot herring (Herklotsichthys quadrimaculatus). Today, deliberate introductions generally employ safeguards to reduce the probability of untoward results. In the case of the proposed introduction of Japanese oysters to Chesapeake Bay, lab-reared, polyploid oysters will be employed, reducing both the likelihood of dispersal of the introduced species (in theory polyploids are sterile) and the inadvertent introduction of associated species. As previously discussed, many species have been inadvertently introduced during oyster introductions. Blake (1999) lists at least eight species of polychaetes that have been introduced in the United States by shipment of oysters. Oyster diseases can also be inadvertently introduced. One of the worst cases of this was the planting of seed oysters from Chesapeake Bay infected with the protozoan Perkinsus marinus in Delaware Bay during the 1950's (Ewart and Ford 1993). Perkinsus (previously known as Dermo or Dermocystidium marinum) causes extensive mortality and, although generally temperature-limited, has had severe effects on Delaware Bay oysters during unusually warm summers.

Control of inadvertent escapes from aquaria or mariculture facilities is more problematic and may require both education and legislation. For instance, culturing species outside their native range requires detailed understanding of the consequences of their escape. Volpe (2001) has summarized the evidence that insufficient care was taken to assess impacts of the mariculture of Atlantic salmon, Salmo salar, in British Columbia. It was assumed prior to establishing the facilities that escaped fish would not be able to survive, breed, establish viable populations, or compete with native species. It has since been shown that escaped salmon not only survive after escape, but can spawn in British Columbia rivers (Volpe et al. 2000). There is some evidence they are competing with native species (Volpe et al. 2001). Adults have been collected as far north as Alaska (Wing et al. 1992).

The largest single source of unintentional introductions, shipping, can be controlled by a combination of antifouling paints and ballast water treatment. Hull fouling has shown to be controllable by application of biocidal paints. Toxic chemicals in the paints either prevent settling or result in mortality when taken up by potential fouling species. The primary difficulty is the nonspecificity of the toxic agents and their potential for transfer to non-target species as evidenced by recent national and international legislation restricting the sale of anti-fouling paints containing tributyltin. 
Development of effective ballast water treatment is also critical to controlling the introduction of invasive species. Carlton et al. (1995) have reviewed the issue and concluded that multiple approaches will be necessary to effectively treat ballast. They indicate that control measures should be applied during uptake, while present in the ballast tank, and during discharge. Treatment at uptake is likely to include filtration to remove large objects such as fish or floating wood scraps that may be harboring boring species. Another option is the construction of facilities to supply treated water for use as ballast. It has also been suggested that incoming ships might deposit their ballast at treatment facilities.

A variety of methods have been suggested for onboard treatment of ballast water. Recommendations include mechanical agitation, alteration of salinity (a procedure already employed), exposure to ultraviolet or microwave radiation, application of biocides, ozonation, heating, and dexoygenation. Heating of ballast water to $38^{\circ} \mathrm{C}$ using waste engine heat has already been successfully field-tested (Rigby et al. 1999). Zooplankton present in the ballast were completely eliminated and much, but not all of the phytoplankton was destroyed. Laboratory tests have also shown that recently developed techniques for reducing ballast tank corrosion using nitrogen to purge oxygen from the water, may have the added benefit of killing many ballast water organisms (Tamburru et al. 2002). Deoxygenating ballast by applying a vacuum has also been successfully tested (Gordon and Horeth 2001). The United States Coast Guard, the agency responsible for approving ballast water treatments for general use, has not officially endorsed any specific method to date. 


\section{Sources of Information}

\section{Basic Literature Sources}

A wide range of books, reports, and journals dealing with invasive species are now available. Simberloff (2004) estimates that nearly 100 books have been published on the subject in the last 10 years. He mischievously notes that there have been more books published on invasive species during this time than records of recent invasions by invasive mollusks. Many of these books are popular accounts of individual species and are of varying quality, yet the sheer quantity is an indication of the growing public awareness of the problem. Academic and governmental reports for marine species certainly equal this total and journal articles and abstracts probably number in the hundreds if not thousands. Wading through all of this information is a daunting task, so in the following chapter, recommendations for essential reading are made.

By far the best and most concise introduction to marine invasions is Carlton's 2001 report for the Pew Ocean Commission entitled "Introduced Species in U.S. Coastal Waters." Williams and Meffe's coverage of the nonindigenous species in the USGS 1999 report, "Status and Trends of the Nation's Biological Resources" provides a similar succinct review of the characteristics of invasive species and habitats susceptible to invasion. The legislative background to the issue, the responsibilities of federal agencies, and a national management plan are all described in "Meeting the Invasive Species Problem" by the National Invasive Species Council (2001). This same group has also produced a detailed outline of the potential pathways for introduction (NISC 2003).

Ruiz and his coauthors have provided two extremely useful reviews of the scientific literature describing first, the environmental impacts resulting from marine and estuarine invasions (Ruiz et al. 1999) and second, the geographic patterns of introduction, pathways, and features of the invasion process (Ruiz et al. 2000). Carlton et al. (1995) is essential reading for anyone interested in the importance of ballast water as a vector. Two chapters in the report are particularly useful. Chapter 4 includes "A Ballast Water Primer," a thorough explanation of what ballast is and how it is used, and "Ballast Water: Operations, How Much, and Where From," a description of ballast water operations. In Chapter 6, the processes of ballast water uptake and discharge are reviewed and 
potential treatment options are discussed. The complete report is available through Connecticut Sea Grant.

As a quick glance at the reference list for this report will show, the scientific accounts of marine and estuarine invasive species are published in a wide variety of journals. The most critical of these seems to be the journal Biological Invasions published by Kluwer Academic Publishing. Journal contents are available on-line and abstracts of articles can be printed from the website (http://www.kluweronline.com/issn/1387-3547/current). Another important source of information is Aquatic Invaders, the digest of the Sea Grant's National Aquatic Nuisance Species Clearinghouse. Issued four times a year, it summarizes recent events and provides abstracts of new journal articles and reports.

\section{Information on the Web}

The invasive species problem has, in a sense, become a public issue at about the same time as the development of the World Wide Web, and as a result, there are a wide range of websites devoted to the issue. In the following section, the websites featuring marine and estuarine animals are described along with their links. Clearly, the most relevant website for the Corps' community is the Aquatic Nuisance Species Research Program's website at http://el.erdc.usace. army.mil/ansrp/ansrp.html. This site provides a quick introduction to the issue, information on species of concern, risk assessment, USACE publications of interest, and links to other websites. The Aquatic Nuisance Species Taskforce (ANS) also provides basic information and, in addition, lists recent management plans such as those for the Chinese mitten crab and the European green crab. It is found at http://www.anstaskforce.gov/. Another essential website is http://invasivespecies.gov/, a site linking information from federal and state programs including the National Aquatic Nuisance Species Council. The site contains multiple links to species profiles, geographic distributions, laws and regulations, vectors, databases, and other resources. It also has a manager's toolkit, links to critical information for environmental managers dealing with NIS problems. The site is found at http://www.invasivespecies.gov/. The United States Geological Survey maintains a particularly useful site for garnering species profiles and downloadable images (http://nas.er.usgs.gov/). The U.S. Environmental Protection Agency's (USEPA) site (http://www.epa.gov/owow/ invasive species/) features both general information and links to its 1999 ballast water report. The Massachusetts Institute of Technology Center for Coastal Resources has a useful site focused primarily on New England waters. It features general information, lists and pictures of local invading species, and of particular importance, downloads of the abstracts of the first three Marine Bioinvasion conferences (http://massbay.mit.edu/exoticspecies/). Sea Grant's National Aquatic Nuisance Species Clearinghouse features a searchable bibliographic database and quick summaries of NIS reports by taxonomic group (http://www.aquaticinvaders.org/nan_ld.cfm). The National Exotic Marine and Estuarine Species Information System or NEMESIS (http://invasions.si.edu/ nemesis/index.html) is the Smithsonian Institution's online searchable database of NIS species information. 
Almost every coastal state either maintains a separate website relating to invasive marine species or is covered by existing Sea Grant, USEPA, or university websites (Table 1). Many states are covered under multiple state, federal, local, and non-governmental websites. The type and amount of information varies considerably, but most include lists of species of local or regional concern and links to additional information sources.

\begin{tabular}{|c|c|}
\hline \multicolumn{2}{|c|}{$\begin{array}{l}\text { Table } 1 \\
\text { Websites for Invasive Species Information by State }\end{array}$} \\
\hline State & URL \\
\hline Alaska & "http://www.adfg.state.ak.us/special/invasive/invasive.php \\
\hline Washington & http://wdfw.wa.gov/fish/ans/ans1.htm \\
\hline Oregon & http://seagrant.oregonstate.edu/hot/exotics.html \\
\hline California & http://cain.nbii.gov/invasivesca \\
\hline Hawaii & http://www.hear.org/AlienSpeciesInHawaii/index.html \\
\hline Texas $^{1}$ & http://www.epa.gov/gmpo/nonindig.html \\
\hline Louisiana $^{2}$ & http://www.cbr.tulane.edu/is/ \\
\hline Mississippi $^{1}$ & http://www.epa.gov/gmpo/nonindig.html \\
\hline Alabama $^{1}$ & http://www.epa.gov/gmpo/nonindig.html \\
\hline Florida $^{2}$ & http://www.floridamarine.org/features/category main.asp?id=1952 \\
\hline South Carolina & http://www.dnr.state.sc.us/water/envaff/aquatic/ \\
\hline North Carolina & http://www.ncseagrant.org/ \\
\hline Virginia & http://invasions.si.edu/ \\
\hline Maryland & http://www.mdsg.umd.edu/exotics/ \\
\hline Delaware & http://www.udel.edu/DISC/ \\
\hline New Jersey & http://sh.nefsc.noaa.gov/ \\
\hline New York & http://www.aquaticinvaders.org/nan Id.cfm \\
\hline Connecticut & http://massbay.mit.edu/exoticspecies/index.html \\
\hline Massachusetts & http://massbay.mit.edu/exoticspecies/index.html \\
\hline Rhode Island & http://massbay.mit.edu/exoticspecies/index.html \\
\hline New Hampshire & http://massbay.mit.edu/exoticspecies/index.html \\
\hline Maine & http://www.cascobay.usm.maine.edu/invasives.html \\
\hline
\end{tabular}

Internationally, there is an equally wide array of websites to choose from. The Global Invasive Species Program (GISP) is one of the best. It maintains a searchable database of international listings of invasive species, provides downloadable reports, lists current news reports, and links to case studies and a newsletter (http://www.gisp.org/). Another source of technical reports relating to invasive species (most of which can be downloaded) is Australia's Centre for Research on Introduced Marine Pests. Their website can be found at http://crimp.marine.csiro.au//reports/publications.html\#techrpt.

Among the non-governmental websites, the Nature Conservancy and the Pew Ocean Commission both have worthwhile websites. The Nature Conservancy website contains an array of information on aquatic and terrestrial invaders and a large library of downloadable reports (http://nature.org/initiatives/ invasivespecies/). The Pew Oceans Commission (http://www.pewoceans.org/ reports/introduced species.pdf) is the site for obtaining Carlton's 2001 report discussed above and a variety of reports on other issues in the marine environment. 


\section{Discussion}

A total of 12 species are identified in this report as existing threats to USACE activities: four are of concern to infrastructure, seven to habitat restoration, and one to USACE divers. Three additional species, not yet present in U.S. waters, are identified that could cause concern in the future. Three of the four that may impact infrastructure are mussels (green, brown, and Asian Date) that may potentially foul water intakes and water control structures. The fourth, the Chinese mitten crab, burrows in creek banks and can undermine earthen levees. Of the seven species identified as potential problems in habitat restoration, one, the Amur River Corbula clam may interfere with the normal recovery of benthic assemblages on newly deposited dredged materials either at placement or beneficial use sites. The veined rapa whelk and the green porcelain crab affect oyster restoration, but in different ways. The whelk feeds directly on oyster spat and young oysters. The crab affects oysters indirectly by providing an alternative food source for species that prey on xanthid crabs, a major predator of oyster spat. The green crab preys on both hard (Mercenaria mercenaria) and soft (Mya arenaria) clams and therefore can disrupt restoration efforts. The burrowing isopods Sphaeroma quoyanum and $S$. terebrans destroy salt marshes and mangroves, respectively. S. quoyanum destabilizes marsh creek banks causing erosion and ultimately bank collapse. Burrowing by $S$. terebrans destroys mangrove prop roots, also causing increased erosion in the newly exposed areas behind the broken roots. The Australian jellyfish, Phylloriza punctata may feed heavily on juvenile fish and fish eggs as well as plankton in the Gulf of Mexico impacting fisheries restoration projects. The venomous lionfish, recently introduced into the South Atlantic, is a danger to divers and any others who may come in contact with them. Two of the three potential future invasive species, the giant fanworm and the Santo Domingo false mussel, are fouling species that have created problems overseas. The mussel, a very close relative of the zebra mussel, may present a particular threat to water intake and control structures. The fanworm, capable of settling on both hard and soft surfaces, fouls underwater structures and might interfere with the normal recolonization of dredged materials at placement or beneficial use sites. The Northern Pacific seastar, a voracious predator of shellfish, has the potential to interfere with shellfish restoration efforts.

Because of its narrow focus, this report does not directly address some of the larger issues associated with invasive species, namely effects on biodiversity and biostability. Biodiversity is the variety of communities, species, and genetic variability within species that make up ecosystems. Invasive species affect 
biodiversity on all three levels. They do so by eliminating or marginalizing native species or by reducing their genetic variability and therefore their viability, through hybridization. Elimination or marginalization of native species potentially alters food web linkages, energy flow, nutrient cycling, and trophic structure. Changes in the ecology of San Francisco Bay resulting from the invasion of Pomatocorbula amurensis are an example of such far-reaching effects. Impacts, however, may be subtler or require long periods of time before their effects become obvious. Comparing field observations and ecological models, Byers and Goldwasser (2001) found that it took 25 years for the invasive snail B. attramentaria to replace the native C. californica on California salt marshes.

Invasive species may also alter the stability of native ecosystems by affecting the way communities respond to disturbance (Mack and D'Atononio 1998). Community structure is regulated, in large part, by the disturbance regime. Very high or low levels of physical or biological disturbance are believed to lead to comparatively low diversity, while intermediate levels are associated with high diversity (the Intermediate Disturbance Hypothesis) (Connell 1978). Invasive species undermine these responses by physically disturbing the environment themselves (e.g., creating tube mats, grazing on algal canopies, bioturbation, etc.) or biologically by altering the way species interact within the community (e.g., displacement of key species, reductions in populations of competing species, etc.). Habitats and their component assemblages display different responses to invasion based on their innate characteristics and prior history of disturbance. As previously mentioned, highly diverse communities such as coral reefs possess a degree of invasion resistance due to the relatively large number of potential competitors present. Yet, they are still susceptible to invasion if stressed. Naturally highly-stressed and relatively low diversity communities, such as those of estuaries, are generally more susceptible to invasion, but may not display immediate deleterious effects. Modelling efforts by Castillio et al. (2000) indicated that the unresponsiveness of some estuarine benthic communities to species invasions may be due to the absence of positive or negative feedback loops in community functional-group interactions. They hypothesize that a critical number of invasions may be required before a response occurs. Likewise, community response may be related to species-specific effects rather than simply the number of invasive species present.

Finally, there is concern that if left unchecked, invasions will produce a homogenization of the world's ecosystems. Instead of there being separate species assemblages endemic to different regions, there would be only a few or perhaps a single, uniform assemblage for each of the major habitat types. Since species populations are often controlled by parasites or disease, the emergence of a new and virulent strain could be catastrophic on a global scale. It is only necessary to look at the decline of the American oyster on the U.S. east coast to see how the emergence of a single disease Haplosporidia nelsoni (also known as MSX) can have devastating effects (Ewarts and Ford 1993).

Problems associated with invasions by marine and estuarine animals are neither new nor for the present time, avoidable. Mankind has deliberately introduced a wide range of species throughout the world and continues to do so 
for purposes of food production or sport. In the past, these introductions have been done with little regard for their ultimate effect on resident species or ecosystems. While this attitude still persists in some, far more care and thought is generally given to species introductions today than in the past. Most introductions are unintentional and facilitated by shipping. The relationship between species introductions and shipping has existed since the earliest days of sail when species hitched a ride in or on wooden hulls or in dry ballast. Today species still travel this way on metal hulls or in ballast water. The difference is that the volume of shipping and the size and speed of ships has increased significantly, making it possible for even more species to be translocated and greatly increasing the rate of species introductions. The best chance for controlling these invasions is preventing them in the first place. Eradication of established populations is often simply impractical. For instance, the Japanese copepod Pseudodiaptomus inopinus is now one of the dominant zooplankters of Puget Sound (Cordell and Morrison 1996). How do you exterminate a copepod from an estuary the size of Puget Sound? For all practical purposes, you can't. Even when eradication is possible, it can be expensive, and when successful, it only eliminates the existing population. It does not prevent further introductions. The best long-term hope for controlling marine invasions is the development of effective ballast water treatment systems. Presently, there are several technologies that hold promise, such as ballast water heating and deoxygenation, but none have been approved or deployed. Until such systems come into general use, we can expect to have to deal with additional unwanted visitors. 


\section{References}

Agard, J., Kishore, R., and Bayne, D. B. (1992). "Perna viridis (Linnaeus, 1758): First record of the Indo-Pacific green mussel (Mollusca: Bivalvia) in the Caribbean," Caribbean Marine Studies 3, 59-60.

Alpine, A. E., and Cloern, J. E. (1992). "Trophic interactions and direct physical effects control phytoplankton biomass and production in an estuary," Limnology and Oceanography 37, 946-955.

Anger, K. (1991). "Effects of temperature and salinity on the larval development of the Chinese Mitten Crab Eriocheir sinensis (Decapoda: Grapsidae)," Marine Biology 72, 103-110.

Aquatic Nuisance Species Task Force (2002). A Draft National Management Plan for the Genus Eriocheir. Report of the Chinese Mitten Crab Control Committee. Available online at http://anstaskforce.gov/.

Bagley, M. J., and Geller, J. B. (1999). "Microsatellite DNA analysis of native and invading populations of European Green crabs." Abstract in: First National Conference on Marine Bioinvasions. January 24-27, 1999. Cambridge, MA. Available online at: http://massbay.mit.edu/ exoticspecies/conferences/1999.

Baker, P., Fajans, J., and Bergquist, D. (2003). "Invasive Green Mussels, Perna viridis, on mangroves and oyster reefs in Florida." Third International Conference on Bioinvasions. March 16-19, 2003, Scripps Institution of Oceanography, La Jolla, CA. Available online at http://massbay.mit.edu/ exoticspecies/conferences/2003.

Bax, N., Hayes, K., Marshall, A., Parry, D., and Thresher, R. (2002). "Man-made marinas as sheltered islands for alien organisms: Establishment and eradication of an alien invasive marine species." Turning the Tide: The eradication of invasive species. C. R. Veitch and M. N. Clout, ed., IUCN SSC Invasive Species Specialist Group, IUCN, Gland, Switzerland and Cambridge, UK, 26-39.

Benson, A. J., Marelli, D. C., Frischer, M. E., Danforth, J. M., and Williams, J. D. (2001). "Establishment of the green mussel, Perna viridis (Linnaeus, 
1758) (Mollusca: Mytilidae) on the west coast of Florida," Journal of Shellfish Research 20, 21-29.

Berman, J., Harris, L., Lambert, W., Buttrick, M., and Dufresne, M. (1992). "Recent invasions of the Gulf of Maine: Three contrasting strategies," Conservation Biology 6, 434-441.

Bertness, M. D. (1984). "Habitat and community modification by an introduced snail,” Ecology 65, 370-381.

Beukema, J. J. (1991). "The abundance of shore crabs Carcinus maenas (L.) on a tidal flat in the Wadden Sea after cold and mild winters," Journal of Experimental Marine Biology and Ecology 153, 97-113.

Bilio, M., and Niermann, U. (2004). "Is the comb jelly really to blame for it al? Mnemiospis leidyi and the ecological concerns about the Caspian Sea," Marine Ecology Progress Series 269, 173-183.

Blake, J. A. (1999). "Shellfish culture as a vector for biological invasions." First National Conference on Marine Bioinvasions. January 24-27, 1999.

Cambridge, MA. Available online at: http://massbay.mit.edu/exoticspecies/ conferences/1999.

Bourdeau, P. E., and O'Connor, N. J. (1999). "Prey preferences of the recently introduced Western Pacific Shore Crab, Hemigrapsus sanguineus, feeding on molluscs and macroalgae in Southeastern Massachusetts." First National Conference on Marine Bioinvasions. January 24-27, 1999. Cambridge, MA. Available online at: http://massbay.mit.edu/exoticspecies/conferences/1999.

Boyd, M. J., Mulligan, T. J., and Shaughnessey, F. J. (2002). "Nonindigenous marine species of Humboldt Bay, California," report to the California Department of Fish and Game, February 28, 2002.

Brenchley, G. A., and Carlton, J. T. (1983). "Competitive displacement of native mud snails by introduced periwinkles in the New England intertidal zone," Biological Bulletin 165, 543-558.

Buddo, D. St. A., Steele, R. D., and D'Oyen, E. R. (2003). "Distribution of the invasive indo-pacific Green Mussel, Perna viridis, in Kingston Harbour, Jamaica," Bulletin of Marine Science 73, 433-441.

Byers, J. E. (2000a). "Competition between two estuarine snails: Implications for invasions of exotic species," Ecology 81, 1225-1239.

. (2000b). "Effects of body size and resource availability on dispersal in a native and a non-native snail," Journal of Experimental Marine Biology and Ecology 248, 133-150.

. (2000c). "Differential susceptibility to hypoxia aids estuarine invasion," Marine Ecology Progress Series 203, 123-132. 
Byers, J. E. (2001). "Physical habitat property mediates biotic resistance to nonindigenous species invasion." Second International Conference on Marine Bioinvasions. April 9-11, 2001. New Orleans, LA. Available online at http://massbay.mit.edu/exoticspecies/conferences/2001.

Byers, J. E., and Goldwasser, L. (2001). "Exposing the mechanism and timing of impact of nonindigenous species on native species," Ecology 82, 1330-1343.

Byrne, M., Morrice, M. G., and Wolf, B. (1997). "Introduction of the northern Pacific asteroid Asterias amurensis to Tasmania: reproduction and current distribution," Marine Biology 127, 673-685.

Carlton, J. T. (1985). "Transoceanic and intraoceanic dispersal of coastal marine organisms: the biology of ballast water," Oceanography and marine biology: An annual review 23, 313-374.

. (1996). "Biological invasions and cryptogenic species," Ecology 77, $1653-1655$.

. (2001). Introduced species in U.S. Coastal Waters: Environmental impacts and management priorities. Pew Oceans Commission, Arlington, VA. Available at http://www.pewoceans.org/reports/introduced_species.pdf.

Carlton, J. T., Chapman, J., Yamadwa, S., Rumrill, S., Burke, J., Fleck, B., Howard, C., Hunt, C., and Palacios, K. (2003). "Introduced species in Oregon estuaries," http://www.bcc.orst.edu/ yamadas.

Carlton, J. T., and Geller, J. B. (1993). "Ecological roulette: The global transport of nonindigenous marine organisms," Science 261, 78-82.

Carlton, J. T., and Hodder, J. (1995). "Biogeography and dispersal of coastal marine organisms: Experimental studies on a replica of a $16^{\text {th }}$ century sailing vessel," Marine Biology 121, 721-730.

Carlton, J. T., and Ruckleshaus, M. H. (1997). "Nonindigenous marine invertebrates and algae." Strangers in Paradise. Impact and Management of Nonidigenous Species in Florida. D. Simberloff, C. Schmitz, and T. C. Brown, ed., Island Press, Washington, DC, 187-201.

Carlton, J. T., Reid, D. M., and van Leeuwen, H. (1995). "Shipping study. The role of shipping in the introduction of nonindigenous aquatic organisms to the coastal waters of the United States (other than the Great Lakes) and an analysis of control options," Report No. CG-D-11-95, The National Sea Grant College Program/Connecticut Sea Grant Project R/ES-6.

Carlton, J. T., Thompson, J. K., Schemel, L. E., and Nichols, F. H. (1990). "Remarkable invasion of San Francisco Bay (California, USA) by the Asian clam Potamocorbula amurensis. I. Introduction and dispersal," Marine Ecology Progress Series 66, 81-94. 
Cassanova, T. (2001). "The ecology of the Japanese Shore Crab (Hemigrasus sanguineus De Haan) and its niche overlap to the Green Crab (Carcinus maenas Linnaeus) along the coast of Connecticut, U.S.A.” Second International Conference on Marine Bioinvasions. April 9-11, 2001. New Orleans, LA. Available online at http://massbay.mit.edu/exoticspecies/ conferences/2001.

Castillo, G. C., Li, H. W., and Rossignol, P. A. (2000). "Absence of overall feedback in a benthic estuarine community: A system potentially buffered from impacts of biological invasions," Estuaries 23, 275-291.

Clapin, G., and Evans, D. R. (1995). "The status of the introduced marine fanworm Sabella spallanzanii in Western Australia: A preliminary investigation," Technical Report 2, Centre for Research on Introduced Marine Pests, CSIRO, Division of Fisheries.

Clark, P. F., Rainbow, P. S., Robbins, R. S., Smith, B., Yeomans, W. E., Thomas, M., and Dobson, A. G. (1998). "The alien Chinese Mitten Crab, Eriocheir sinensis (Crustacea: Decapoda: Brachyura), in the Thames catchment," Journal of the Marine Biological Association of the United Kingdom 78, 1215-1221.

Cohen, A. N., and Carlton, J. T. (1995). "Biological study. Nonindigenous aquatic species in a United States estuary: A case study of the biological invasions of the San Francisco Bay and Delta," report for the United States Fish and Wildlife Service and the National Sea Grant Program, Connecticut Sea Grant Publication PB96-166525, Washington, DC.

. (1998). "Accelerating invasion rate in a highly invaded estuary," Science 279, 555-558.

Cohen, A. N., Carlton, J. T., and Fountain, M. C (1995). "Introduction, dispersal and potential impacts of the green crab Carcinus maenas in San Francisco Bay, California," Marine Biology 122, 225-237.

Coles, S. L., and Eldridge, L. G. (2002). "Nonindigenous species introductions on coral reefs: A need for information," Pacific Science 56, 191-209.

Coles, S. L., DeFelice, R. C., Eldridge, L. G., and Carlton, J. T. (1999). "Historical and recent introductions into Pearl Harbor, Oahu, Hawaiian Islands," Marine Biology 135, 147-158.

Committee for Research on Introduced Marine Pests (2001). "Giant Fanworm (Sabella spallanzanii)," CRIMP Infosheet 6, Marine Pest Information Sheet.

Connell, J. H. (1978). "Diversity in tropical rain forests and coral reefs," Science 199, 1302-1310. 
Cordell, J. R., and Morrison, S. M. (1996). "The invasive Asian copepod Pseuododiaptomus inopinus in Oregon, Washington, and British Columbia estuaries," Estuaries 19, 629-638.

Crooks, J. A. (1996). "The population ecology of an exotic mussel, Musculista senhousia, in a Southern California bay," Estuaries 19, 42-50.

. (1998). "Habitat alteration and community-level effects of an exotic mussel, Musculista senhousia," Marine Ecology Progress Series 162, 137152.

. (2002). "Predators of the invasive mussel Musculista senhousia (Mollusca: Mytilidae)," Pacific Science 56, 49-56.

Crooks, J. A., and Khim, H. S. (1999). "Architectural vs. biological effects of a habitat-altering, exotic mussel, Musculista senhousia," Journal of Experimental Marine Biology and Ecology 240, 53-75.

Culver, C. S., and Kuris, A. M. (1999). "The sabellid pest of abalone: The first eradication of an established introduced marine bioinvader?" First National Conference on Marine Bioinvasions. January 24-27, 1999. Cambridge, MA. Available online at: http://massbay.mit.edu/exoticspecies/conferences/1999.

. (2000). "The apparent eradication of a locally established introduced marine pest," Biological Invasions 2, 245-253.

Culver, C. S., and Walter, M. H. (2001). "Prospective management of the Chinese Mitten Crab: evaluation of a passive trapping system." Second International Conference on Marine Bioinvasions. April 9-11, 2001. New Orleans, LA. Available online at http://massbay.mit.edu/exoticspecies/ conferences/2001.

Dauer, D. (1984). "Functional morphology and feeding behaviour of Streblspio benedicti (Polychaeta: Spionidae)." Proceeding of the First International Polychaete Conference, P. A. Hutchings, ed., Linnean Society of New South Wales, 418-429.

DeFelice, R. C., Eldridge, L. G., and Carlton, J. T. (2001). "Nonindigenous marine invertebrates." A guidebook of introduced Species in Hawaii. L. G. Eldridge and C. M. Smith, ed., Bishop Museum Technical Report 21, B1-20.

Department of Fisheries, Government of Western Australia (2004). "Northern Pacific Seastar."Guide to Introduced Marine Species. At: http://www.fish. wa.gov.au/hab/broc/marineinvader/.

de Rivera, C. E., Jivoff, P. R., Hines, A. C., and Ruiz, G. M. (2003). "Invasion limitation by biotic versus physical factors: Does Callinectes sapidus limit Carcinus maenas population size and distribution in eastern North America." Third International Conference on Bioinvasions. March 16-19, 2003, La 
Jolla, CA. Available online at http://massbay.mit.edu/exoticspecies/ conferences $/ 2003$

Dixon, J., Schroeter, S. C., and Kastendiek, J. (1981). "Effects of the encrusting bryozoan, Membranipora menbranacea, on the loss of blades and fronds by the Giant Kelp, Macrosystis pyrifera (Laminariales)," Journal of Phycology 17, 341-345.

Draheim, R. C., Cordell, J. R., Sytsma, M. D., and Chapman, J. W. (2003). "Aquatic nonindigenous species in the changing Lower Columbia River estuary, USA." Third International Conference on Bioinvasions. March 1619, 2003, Scripps Institution of Oceanography, La Jolla, CA. Available online at http://massbay.mit.edu/exoticspecies/conferences/2003/index.html.

Dudas, S. E., McGaw, I. J., and Dower, J. F. (2003). "Foraging behavior of two crab species on native and non-indigenous bivalves in coastal British Columbia." Third International Conference on Bioinvasions. March 16-19, 2003, Scripps Institution of Oceanography, La Jolla, CA. Available online at http://massbay.mit.edu/exoticspecies/conferences/2003/index.html.

Eldridge, L. G., and Carlton, J. T. (2002). "Hawaiian marine bioinvasions: A preliminary assessment," Pacific Science 56, 211-212.

Eldridge, L. G., and Evenhuis, N. L. (2002). "Numbers of Hawaiian species for 2000." Records of the Hawaii Biological Survey for 2000. Bishop Museum Occasional Papers 68, 71-78.

Elton, C. S. (1958). The ecology of invasions by animals and plants. 2000 ed., University of Chicago Press, Chicago, IL.

Epifaunio, C. E., Dittel, A. I., Park, S., Scwalm, S., and Fouts, A. (1990). "Early life history of Hemigrapsus sanguineus, a non-indigenous crab in the Middle Atlantic Bight (USA)," Marine Ecology Progress Series 170, 231-238.

Erlich, P. R. (1989). "Attributes of Invaders and the Invading Processes: Vertebrates." Biological invasions: A global perspective. J. A. Drake et al., ed., 1989 SCOPE. John Wiley and Sons, Ltd, 315-328. Available on-line at http://www.icsu-scope.org/downloadpubs/scope37/scope37.html.

Ewart, J. W., and Ford, S. E. (1993). "History and impact of MSX and Dermo diseases on oyster stocks in the Northeast region," Northeast Regional Aquaculture Center Fact Sheet 200.

Federal Register. (1999). Executive Order 13112 of February 3, 1999-Invasive Species. Federal Register 64 No. 25. Available at http://www.invasivespecies.gov/laws.

Felder, D. L. (1973). An annotated key to crabs and lobsters (Decapoda, Reptantia) from coastal waters of the Northwestern Gulf of Mexico. Louisiana Sea Grant publication LSU-SG-73-02. 
Feyrer, F., Herbold, B., Matern, S., and Moyle, P. B. (2003). "Dietary shifts in a stressed fish assemblage: Consequences of a bivalve invasion in the San Francisco Estuary," Environmental Biology of Fishes 67, 277-288.

Forrester, C. R., Peden, A. E., and Wilson, R. M. (1972). "First records of the striped bass in British Columbia waters," Journal of the Fisheries Research Board of Canada 29, 337-339.

Gare, J. A., and Whitfield, P. E. (2003). "An integrated assessment of the introduction of Lionfish (Pterois volitans/miles complex) to the Western Atlantic Ocean," National Atmospheric and Oceanographic Administration, National Ocean Service Technical Memorandum CCFHR 1.

Geller, J. B. (1999). "Decline of a native mussel masked by sibling species invasion," Conservation Biology 13, 661-664.

Global Invasive Species Database (2004). "Mytilus galloprovincialis, mollusc." Website at http://www.invasives.org/database/welcome.

Glude, J. B. (1955). "The effects of temperature and predators on the abundance of the soft-shell clam, Mya arenaria, in New England," Transactions of the American Fisheries Society 84, 13-24.

Goddard, J. H. R. (2001). "Experimental infection of native California crabs by Sacculina carcini, a potential biocontrol agent of introduced European crabs." Second International Conference on Marine Bioinvasions. April 9-11, 2001. New Orleans, LA. Available online at http://massbay.mit.edu/exoticspecies/conferences/2001/.

Godwin, L. S., and Eldridge, L. G (1999). "Hull fouling and ballast sediments: The importance of vectors other than ballast water in transporting nonindigenous marine species in the Hawaiian Islands." First National Conference on Marine Bioinvasions. January 24-27, 1999. Cambridge, MA. Available online at: http://massbay.mit.edu/exoticspecies/conferences/1999.

Gollasch, S., MacDonald, E., Belson, S., Botnen, H., Christensen, J. T., Hamer, J. P., Houvenaghel, G., Jelmert, A., Lucas, I., Masson, D., McCollin, T., Olenin, S., Persson, A., Wallentinus, I., Wetsteyn, L. P. M. J., and Wittling, T. (2002). "Life in ballast tanks." Invasive species of Europe-Distribution, impact and management. E. Leppakoski, S. Gollash, and S. Olenin, ed., Kluwer Academic Publishing, Dordrecht, 217-231.

Gordon, A. S., and Horeth, D. (2001). "Evaluation of the effectiveness of the AquaHabitat $^{\mathrm{TM}}$ system for treatment of ballast water." Second International Conference on Marine Bioinvasions. April 9-11, 2001. New Orleans, LA. Available online at http://massbay.mit.edu/exoticspecies/conferences/2001/.

Gottleib, S. A., and Schweighofer, M. E. (1996). "Oysters and the Chesapeake Bay ecosystem: A case for exotic species introduction to improve environmental quality," Estuaries 19, 639-650. 
Goulletquer, P., Bachelet, G., Sauriau, P. G., and Noel, P. (2002). "Open Atlantic coast of Europe: A century of introduced species into French waters." Invasive species of Europe-Distribution, impact and management. E. Leppakoski, S. Gollash, and S. Olenin, ed., Kluwer Academic Publishing, Dordrecht, 276-290.

Graham, W. M., Martin, D.L., Felder, D. L., Asper, V. L., and Perry, H. M. (2003). "Ecological and economic implications of a tropical jellyfish invader in the Northern Gulf of Mexico," Biological Invasions 5, 53-69.

Graham, W. M., Perry, H. M., and Felder, D. L. (2001). "Ecological and economic implications of the tropical jellyfish Phylloriza punctata in the Northern Gulf of Mexico during the summer of 2000." Second International Conference on Marine Bioinvasions. April 9-11, 2001. New Orleans, LA. Available online at http://massbay.mit.edu/exoticspecies/conferences/2001/.

Gray Hitchcock, N., Teck, S., Lipski, D., Steves, B., de Rivera, C., and Ruiz, G. (2003). "Predicting European green crab, Carcinus maenas, invasion in Alaska." Third International Conference on Bioinvasions. March 16-19, 2003, Available online at http://massbay.mit.edu/exoticspecies/ conferences/2003.

Grigg, R., and Kelley, C. (2002). "Sustainability of the black coral fishery in Hawai'i and impacts on bottomfish habitat." National Undersea Research Center for Hawaii and the Western Pacific-Q4 2002 Milestone Report. National Undersea Research Center for Hawaii and the Western Pacific. Available online at http://www.soest.hawaii.edu/HURL/Q4 2002.html.

Grosholz, E. D., and Ruiz, G. M. (1995). "Spread and potential impact of the recently introduced European green crab Carcinus maenas, in Central California," Marine Biology 122, 239-247.

Grosholz, E., and Ruiz, G. (eds.) (2002). Management plan for the European green crab. Submitted to the Aquatic Nuisance Species Task Force. March 1, 2002. Available online at http://anstaskforce.gov/.

Gulf States Marine Fisheries Commission (2003). "Fact Sheet for Perna perna." Available online at http://nis.gsmfc.org.

Hanfling, B., Carvalho, G. R., and Brandl, R. (2002). "mt-DNA sequences and possible invasion pathways of the Chinese Mitten Crab," Marine Ecology Progress Series 238, 307-310.

Harding, J. M. (2003). "Predation by blue crabs, Caliinectes sapidus, on rapa whelks, Rapana venossa: Possible natural controls for an invasive species?" Journal of Experimental Marine Biology and Ecology 297, 161-177.

Harding, J. M., and Mann, R. (1999). "Observations on the biology of the veined rapa whelk, Rapana venosa (Valenciennes, 1846) in the Chesapeake Bay," Journal of Shellfish Research 18, 9-18. 
. (2000). "Larval ecology of Veined Rapa Whelk Rapana venosa from Chesapeake Bay." $4^{\text {th }}$ International Larval Biology Conference, June 24-28, 2000. Santa Cruz, CA.

Harding, J. M., and Mann, R. (2001). "Growth rates of larval and juvenile rapa whelks Rapana venosa from Chesapeake Bay, U.S.A.: From hatch through age I." Second International Conference on Bioinvasions. 2001, New Orleans, LA. Available online at http://massbay.mit.edu/exoticspecies/ conferences/2001

Hartman, M. J., Stancyk, S E., and Lohrer, A. M. (2001). "An invasive crab, Petrolisthes armatus, as alternative prey in an oyster reed ecosystem." $16^{\text {th }}$ Biennial Conference of the Estuarine Research Federation, November 4-8, 2001. St. Petersburg Beach, Florida. Available on-line at http://ero.org/erf2001.

Hassler, T. J. (1988). "Species profiles: Life histories and environmental requirements of coastal fishes and invertebrates (Pacific Southwest) - Striped bass," U.S. Fish and Wildlife Service Biological Report 82(11.82), Technical Report EL-82-4, U.S. Army Engineer Waterways Experiment Station, Vicksburg, MS.

Hewitt, C. L. (2002). "Distribution and biodiversity of Australian tropical marine Bioinvasions," Pacific Science 56, 213-222.

Hicks, D. W., and Tunnell, J. W., Jr. (1993). "Invasion of the south Texas coast by the edible brown mussel Perna perna (Linnaeus, 1758)," Veliger 36, 9294.

. (1995). "Ecological notes and patterns of dispersal in the recently introduced mussel, Perna perna (Linne 1758), in the Gulf of Mexico," Amercan Malacological Bulletin 11, 203-206.

Hicks, D. W., Tunnell, J. W., Jr, and McMahon, R. F. (2001). "Population dynamics of the noningigenous brown mussel Perna perna in the Gulf of Mexico compared to other worldwide populations," Marine Ecology Progress Series 211, 181-192.

Hollaway, M. G., and Keough, M. J. (2002). "An introduced polychaete affects recruitment and larval abundance of sessile invertebrates," Ecological Applications 12, 1803-1823.

Hollebone, A. L., and Hay, M. E. (2003). "An invasive crab in the South Atlantic Bight; friend or foe?" Third International Conference on Bioinvasions. March 16-19, 2003, La Jolla, CA. Available online at http://massbay.mit.edu/ exoticspecies/conferences/2003.

Hunt, C. E., and Yamada, S. B. (2003). "Biotic resistance experienced by an invasive crustacean in a temperate estuary," Biological Invasions 5, 33-43. 
Hutchings, P., and Glasby, C. (2004). "Port surveys for introduced species-and the fate of the material, collected," Marine Pollution Bulletin 48, 1009-1011.

Ingrao, D. A., Mikkelsen, P. M., and Hicks, D. W. (2001). "Another introduced marine mussel in the Gulf of Mexico: The Indo-Pacific green mussel Perna viridis (Linnaeus, 758) in Tampa Bay, Florida," Journal of Shellfish Research 20, 12-29.

Jensen, G. C., and Armstrong, D. A. (2004). "The occurrence of the Japanese Mitten crab, Eriocheir japonica (De Haan), on the west oast of North America," California Fish and Game 90, 94-99.

Jensen, G. C., McDonald, P. S., and Armstrong, D. A. (2002). "East meets west: Competitive interactions between green crab Carcinus maenas, and native and introduced shore crab Hemigrapsus sp.," Marine Ecology Progress Series 225, 251-262.

Jensen, K. T., and Jensen, J. N. (1985). “The importance of some epibenthic predators on the density of juvenile benthic macrofauna in the Danish Wadden Sea," Journal of Experimental Marine Biology and Ecology 89, 157-174.

Kideys, A. E. (2003). "The comb jelly Mnemiopsis leiydii in the Black Sea." Invasive species of Europe-Distribution, impact and management. E. Leppakoski, S. Gollash, and S. Olenin, ed., Kluwer Academic Publishing, Dordrecht, 56-61.

Kimmerer, W. J., Gartside, E., and Orsi, J. J. (1994). "Predation by an introduced clam as the likely cause of substantial declines in zooplankton of San Francisco Bay," Marine Ecology Progress Series 113, 81-93.

Knott, D., Boyko, C., and Harvey, A. (1999). "Introduction of the Green Porcelain crab, Petrolisthes armatus (Gibbes, 1850) into the South Atlantic Bight." First National Conference on Marine Bioinvasions. January 24-27, 1999. Cambridge, MA. Available online at: http://massbay.mit.edu/ exoticspecies/conferences/1999.

Lambert, W. J., Levin, P. S., and Berman, J. (1992). "Changes in the structure of a New England kelp bed: the effects of an introduced species?" Marine Ecology Progress Series 88, 303-30.

Lavoie, D. M., Smith, L. D., and Ruiz, G. M. (1999). “The potential for intracoastal transfer of nonindigenous species in the ballast water of ships," Estuarine, Coastal and Shelf Science 48, 551-654.

Lee II, H., Nelson, W., Lamberson, J., and Reusser, D. (2003). "Regional assessment of the invasive macrobenthos in the small west coast estuaries." Third International Conference on Bioinvasions March 16-19, 2003, La Jolla, CA. Available online at http://massbay.mit.edu/exoticspecies/ conferences/2003. 
Lee II, H., Thompson, B., and Lowe, S. (2003). "Estuarine and scalar patterns of invasion in the soft-bottom benthic communities of the San Francisco Estuary," Biological Invasions 5, 85-102.

Levin, L. A. (1984). "Multiple patterns of development in Streblospio benedicti Webster (Spionidae) from three coasts of North America," Biological Bulletin 166, 494-508.

Levin, L. A., Caswell, H., DePatra, K. D., and Creed, E. L. (1987). "Demographic consequences of larval development mode: Planktotrophy vs. leicthotrophy in Streblospio benedicti," Ecology 68, 1877-1886.

Lohrer, A. M. (2001). "The threat of invasion in South Carolina estuaries: a focus of exotic decapod crabs." $16^{\text {th }}$ Biennial Conference of the Estuarine Research Federation, November 4-8, 2001. St. Petersburg Beach, Florida. Available on-line at http://ero,org/erf2001.

Lohrer, A. M., and Whitlach, R. B. (1997). "Ecological studies on the recently introduced Japanese Shore Crab (Hemgrapsus sanguineus), in Eastern Long Island Sound." Proceedings of the $2^{\text {nd }}$ Northeast Conference on Nonindigenous Aquatic Nuisance Species, Connecticut Sea Grant Publication CTSG-97-02, 49-60.

Mack, M. C., and D'Antonio, C. M. (1998). "Impacts of biological invasions on disturbance regimes," Trends in Ecology and Evolution 13, 195-198.

Mann, R., and Harding, J. M. (2000a). "Invasion of the North American Atlantic Coast by a large predatory Asian mollusc," Biological Invasions 2, 7-22.

. (2000b). "Variability in larval development of Veined Rapa Whelk Rapana venosa from Chesapeake Bay, USA: Implications for ecological success in local habitats." $4^{\text {th }}$ International Larval Biology Conference, June 24-28, 2000. Santa Cruz, CA.

. (2003). "Salinity tolerance of Rapana venosa: implications for dispersal and establishment of an invading predatory gastropod on the North American Atlantic Coast," Biological Bulletin 204, 96-103.

Marelli, D. C., and Gray, S. (1985). "Comments on the status of recent members of the genus Mytilopsis (Bivalvia: Dressenidae)," Malacological Review 18, $117-122$

Martel, C., Viard, F., Bourguet, D., and Garcia-Meunier, P. (2004). "Invasion by the marine gastropod Ocinebrellus inornatus in France; 1. Scenario for the source of introduction," Journal of Experimental Marine Biology and Ecology 306, 155-170.

Mascaro, M., and Seed, R. (2000a). "Foraging behavior of Carcinus maenas (L.): Comparisons of size-selective predation on four species of bivalve prey," Journal of Shellfish Research 19, 283-291. 
Mascaro, M., and Seed, R. (2000b). "Foraging behavior of Carcinus maenas (L.): Species-selective predation among four bivalve prey," Journal of Shellfish Research 19, 293-300.

May, J. T., and Brown, L. R. (2001). Chinese Mitten Crab surveys of San Joaquin River Basin and Suisun March, California, 2000. U.S. Geological Survey. Open Report 01-396.

McDonald, P. S., Jensen, G. C., and Armstrong, D. A. (2001). "The competitive and predatory impacts of the nonindigenous crab Carcinus maenas (L.) on early benthic phase Dungeness crab Cancer magister Dana," Journal of Experimental Marine Biology and Ecology 258, 39-54.

McDonald, P. S., Jensen, G. C., Carr, L., Dumbauldt, B. R., and Armstrong, D. A. (2001). "Possible biological constraints on spatial distribution and abundance of the nonindigenous crab Carcinus maenas (L.) on the west coast of North America." Second International Conference on Bioinvasions. 2001, New Orleans, LA. Available online at http://massbay.mit.edu/ exoticspecies/conferences/2001.

Miller, T. W. (1996). "First record of the green crab Carcinus maenas in Humboldt Bay, California," California Fish and Game 82, 93-96.

Mills, C. E. (2004). "Nuttallia obscurata, the purple varnish clam or purple mahogany-clam," Electronic document available at http://faculty.washington. $\underline{\text { edu/cemills/Nuttallia.html. }}$.

Mills, C E., and Sommer, F. (1995). "Invertebrate introductions in marine habitats: Two species of hydromedusae (Cnidaria) native to the Black Sea, Maeotis inexpectata and Blackfordia virginica, invade San Francisco Bay," Marine Biology 122, 279-288.

Minchin, D., and Gollasch, S. (2002). "Vectors: How exotics get around." Invasive species of Europe-Distribution, impact and management. E. Leppakoski, S. Gollash, and S. Olenin, ed., Kluwer Academic Publishing, Dordrecht, 183-192.

Mistri, M. (2002). "Ecological characteristics of the invasive Asian Date Mussel, Musculista senhousia, in the Sacca di Goro (Adriatic Sea, Italy)," Estuaries 25, 431-440.

Moksnes, P.-O. (2002). "The relative importance of habitat-specific settlement, predation, and juvenile dispersal for distribution and abundance of young juvenile shore crabs Carcinus maenas L," Journal of Experimental Marine Biology and Ecology 271, 41-73.

Morris, R. H., Abbott, D. P., and Haderlie, E. C. (1980). Intertidal Invertebrates of California. Stanford University Press, Stanford, CA. 
National Invasive Species Council. (2001). "Management plan, meeting the invasive species challenge," National Invasive Species Council. January 18, 2001. Available online at http://www.invasivespecies.gov/council/mp.pdf. . (2003). "Pathways of introduction of invasive species. Final report," Invasive Species Pathways Team. National Invasive Species Council. October 29, 2003.

National Oceanographic and Atmospheric Administration. (2001). "Chinese Mitten Crabs appear free of lung flukes." National Oceanographic and Atmospheric Administration, Sea Grant Current News November 14, 2001. Available online at http://www.seagrantnews.org/news/ 20011114 chines.html.

Nehring, S. (2002). "Biological invasions into German waters: An evaluation of the importance of different human-mediated vectors for nonindigenous macrozoobenthic species." Invasive species of Europe--Distribution, impact and management. E. Leppakoski, S. Gollash, and S. Olenin, ed., Kluwer Academic Publishing, Dordrecht, 373-383.

Nepszy, S. J., and Leach, J. H. (1975). "First records of the Chinese Mitten Crab, Eriocheir sinensis, (Crustacea: Brachyura) from North America," Journal of the Fisheries Research Board of Canada 30, 1909-1910.

Nichols, F. H., Thompson, J. K., and Schemel, L. E. (1990). "Remarkable invasion of San Francisco Bay (California, USA) by the Asian clam Potamocorbula amurensis. II. Displacement of a former community," Marine Ecology Progress Series 66, 81-94.

Nonindigenous Aquatic Species Database (2004). "Search on Mytilus provincialis performed 2004," http://nas.er.usgs.gov/queries.

O'Connor, N. J. (2001). “The Asian shore crab Hemigrapsus sanguineus in New England: Changes in resident crab populations?" Second International Conference on Bioinvasions. 2001, New Orleans, LA. Available online at http://massbay.mit.edu/exoticspecies/conferences/2001.

O’Neill, C. R., Jr. (2001). "Salinity tolerance of larval Rapana venosa: Implications for dispersal and establishment range on the U.S. east coast." Second International Conference on Bioinvasions. 2001, New Orleans, LA. Available online at http://massbay.mit.edu/exoticspecies/conferences/2001.

Osman, R. W., and Whitlach, R. B. (1995). "Ecological factors controlling the successful invasion of three species of ascidians into marine subtidal habitats of New England." Proceedings of the Northeast Conference on NonIndigenous Aquatic Nuisance Species. Connecticut Sea Grant Publication CT-SG-95-04, 49-60. 
Padilla, D. K., and Williams, S. L. (2004). "Beyond ballast water: Aquarium and ornamental trades as sources of invasive species in aquatic ecosystems," Frontiers in Ecology and the Environment 3, 131-138.

Park, S. (1999). "Early life history of Hemigrapsus sanguineus, a nonindigenous crab in the Middle Atlantic Bight." First National Conference on Marine Bioinvasions. January 24-27, 1999. Cambridge, MA. Available online at: http://massbay.mit.edu/exoticspecies/conferences/1999.

Perry, D. M., and Brusca, R. C. (1989). "Effects of the root-boring isopod Sphaeroma peruvianum on red mangrove forests," Marine Ecology Progress Series 57, 287-292.

Pihl, L. (1985). "Food selection and consumption of mobile epibenthic fauna in shallow marine areas," Marine Ecology Progress Series 22, 169-179.

Race, M. S. (1982). "Competitive displacement and predation between introduced and native mud snails," Oecologia 54, 337-347.

Randall, J. E. (1987). "Introductions of marine fishes to the Hawaiian islands," Bulletin of Marine Science 41, 490-502.

Rehm, A., and Humm, H. J. (1972). "Sphaeroma terebrans: A threat to the mangroves of Southwestern Florida," Science 182, 173-174.

Reutsch, T. B. H. (1998). "Native predators contribute to invasion resistance to the nonindigenous bivalve Musculista senhousia in southern California," Marine Ecology Progress Series 170, 159-168.

Reutsch, T. B. H., and Williams, S. L. (1998). "Variable response of native eelgrass Zostera marina to a nonindigenous bivalve Musculista senhousia," Oecologia 113, 428-441.

Ribi, G. (1981). "Does the wood boring isopod Sphaeroma terebrans benefit red mangroves (Rhizophora mangle)," Bulletin of Marine Science 31, 925-928.

Rigby, G. R., Hallegraeff, G. M., and Sutton, C. (1999). "Novel ballast water heating treatment offers cost-effective treatment to reduce risk of global transport of harmful marine organisms," Marine Ecology Progress Series 191, 289-293.

Ropes, J. W. (1968). "The feeding habits of the green crab, Carcinus maenas (L.)," Fishery Bulletin 67, 183-203.

Ross, D. J., Johnson, C. R., Hewitt, C. L., and Ruiz, G. M. (2004). "Interaction and impacts of two introduced species on a soft-sediment marine assemblage in SE Tasmania," Marine Biology 144, 747-756.

Rudnick, D. A., and Resh, V. H. (2002). "A survey to examine the effects of the Chinese Mitten Crab on commercial fisheries in Northern California," 
Interagency Ecology Program for the San Francisco Estuary Newsletter 15, 19-21.

Rudnick, D. A., and Resh, V. H. (2003). "Trophic ecology of the Chinese Mitten Crab in the San Francisco Bay: Implications for aquatic food webs." Third International Conference on Bioinvasions. March 16-19, 2003, La Jolla, CA. Available online at http://massbay.mit.edu/exoticspecies/conferences/2003.

Ruiz, G. M., Fofonoff, P., and Hines, A. H. (1999). "Nonindigenous species as stressors in estuarine and marine communities: Assessing invasion impacts and interactions," Limnology and Oceanography 44, 950-972.

Ruiz, G. M., Fofonoff, P., Carlton, J. T., Wonham, M. J., and Hines, A. H. (2000). "Invasion of coastal marine communities in North America: Apparent patterns, processes, and biases," Annual Review in Ecology and Systematics 2000, 481-531.

Rylander, K., Perez, J., and Gomez, J. A. (1996). "Status of the green mussel Perna viridis (Linnaeus, 1758) (Mollusca: Mytillidae), in northeastern Venezuela," Caribbean Marine Studies 5, 86-87.

Sakai, A. K., Allendorf, F. W., Holt, J. S., Lodge, D. M., Molofsky, K. A., With, K. A., Baughman, S., Cabin, R. J., Cohen, J. E., Ellstrand, N. C., McCauley, D. E., O’Neil, I. M., Thompson, J. E., and Weller, S. G. (2001). "The population biology of invasive species," Annual Review of Ecology and Systematics 32, 305-332.

Sanchez-Salazar, M. E., Griffiths, C. L., and Seed, R. (1987a). "The interactive roles of predation and tidal elevation in structuring populations of the edible cockle Cerastoderma edule," Estuarine, Coastal and Shelf Science 25, 245260 .

. (1987b). "The effect of size and temperature on the predation of cockles Cerastoderma edule (L.) by the shore crab Carcinus maenas (L.)," Journal of Experimental Marine Biology and Ecology 111, 181-193.

Scattergood, L. W. (1952). "The distribution of the green crab Carcinides maenas (L.), in the Northwestern Atlantic," Maine Department of Sea Shore Fisheries, Fishery Circular 8, 2-10.

Segnini de Bravo, M. I., Chung, K. S., and Perez, J. E. (1998). "Salinity and temperature tolerances of green and brown mussels, Perna viridis and Perna perna (Bivalvia: Mytilidae)," Revue de Biologia Tropical 5, 121-125.

Shiganova, T. A., Mirzoyan, Z. A., Studenikina, E. A., Volovik, S. P., SiokouFrangou, I., Zervoudaki, S., Cristou, E. D., Skirta, A. Y., and Dumont, H. J. (2001). "Population development of the invader ctenophore Mnemiopsis leiydi, in the Black Sea and in other areas of the Mediterranean Basin," Marine Biology 139, 431-445. 
Simberloff, D. (2004). "A riding tide of species and literature: A review of some recent books on biological invasions," BioScience 54, 247-254.

Simberloff, D., Brown, B. J., and Lowrie, S. (1978). "Isopod and insect root borers may benefit Florida mangroves," Science 201, 630-632.

Smith, L. D., and Trussell, G. C. (1999). 'The influence of water temperature on induced defensive responses by an intertidal snail to an introduced crab predator." First National Conference on Marine Bioinvasions. January 2427, 1999. Cambridge, MA. Available online at: http://massbay.mit.edu/ exoticspecies/conferences/1999.

Snelgrove, P. V. R. (1997). "The importance of marine sediment biodiversity in ecosystem processes,” Ambio 26, 578-583.

. (1999). "Getting to the bottom of marine biodiversity: Sedimentary habitats," BioScience 49, 129-138.

Southward, A. J., Burton, R. S., Coles, S. L., Dando, P. R., DeFelice, R. C., Hoover, J., Parnell, P. E., Yamaguchi, T., and Newman, W. A. (1998). "Invasion of Hawaiian shores by an Atlantic barnacle," Marine Ecology Progress Series 165, 119-126.

Sutton, C. A., and Bruce, B. D. (1996). "Temperature and salinity tolerances of the larvae of the Northern Pacific Seastar, Asterias amurensis." Centre for Research on Introduced Marine Pests, Technical Report 6. CSIRO, Division of Fisheries.

Stachowicz, J. L., Terwin, J. R., Whitlach, R. B., and Osman, R. W. (2002). "Linking climate change and biological invasions: Ocean warming facilitates nonindigenous species invasions." Proceedings of the National Academy of Sciences 99, 15497-15550.

Talley, T. S., Crooks, J. A., and Levin, L. A. (2001). "Habitat utilization and alteration by the invasive, burrowing isopod, Sphaeroma quoyanum, in California salt marshes," Marine Biology 138, 561-573.

Tamburru, M. N., Wasson, K., and Matsuda, M. (2002). "Ballast water deoxygenation can prevent aquatic introductions while reducing ship corrosion," Biological Conservation 103, 331-341.

Torchin, M. E., Lafferty, and Kuris, A. M. (1996). "Infestation of an introduced host, the European green crab, Carcinus maenas, by a symbiotic nemertean egg predator, Carcinonemertes epialti," Journal of Parasitology 82, 449-453.

Torchin, M. E., Lafferty, K. D., Dobson, A. P., McKensie, V. J., and Kuris, A. M. (2003). "Introduced species and their missing parasites," Nature 421, 628-630. 
Uebelacker, J. M., and Johnson, P. G., ed. (1984). Taxonomic Guide to the Polychaetes of the Northern Gulf of Mexico. Final Report to the Minerals Management service, Contract 14-12-001-29091. Barry Vittor and Associates, Inc. Mobile, AL.

U.S. Fish and Wildlife Service (USFWS) News Release. (2003). "New York fish importer sentenced to prison for illegally importing mitten crabs," U.S. Fish and Wildlife Service News Release July 22, 2003. http://news.fws.gov/ newsreleases/r5/F74A4CEC-2E6A-4CA3-8E2CDB6B0A0E409B.html.

U.S. Geological Survey (USGS). (1998). United States Geological Survey, Nonindigenous Aquatic Species Website. http://nas.er.usgs.gov/algae/ sa mutic.html.

. (2001). "Green mussel, Perna viridis (Linnaeus, 1758) (Mollusca: Mytilidae)," United States Geological Survey, Nonindigenous Species Information Bulletin No. 2001-002. May 15, 2001. Available online at http://cars.er.usgs.gov/greenmussel4.pdf.

Velarde, R. G., Cadien, D. B., Mikel, T. K., Ranasinghe, J. A., and Lee, H. (2003). "The prevalence of nonindigenous species in Southern California embayments and their effects on benthic macroinvertebrate communities." Third International Conference on Bioinvasions. March 16-19, 2003, La Jolla, CA. Available online at http://massbay.mit.edu/exoticspecies/ conferences/2003.

Veldhuizen, T., and Stanish, S. (2002). "Overview of the life history, distribution, abundance, and impacts of Chinese mitten crab Eriocheir sinensis." A Draft National Management Plan for the Genus Eriocheir. Aquatic Nuisance Species Task Force. February 2002. 37-5. Available online at http://asntaskfoce.gov.

Volpe, J. P. (2001). Super un-natural. Atlantic Salmon in BC waters. David Suzuki Foundation, Vancouver, British Columbia.

Volpe, J. P., Anholt, R., and Glickman, B. W. (2001). "Competition among juvenile Atlantic salmon (Salmo salar) and steelhead (Oncorhynchus mykiss): Relevance to invasion potential in Brirish Columbia," Canadian Journal of Fisheries and Aquatic Science 58, 197-207.

Volpe, J. P., Taylor, E. B., Rimmer, D. W., and Glickman, B. W. (2000). "Evidence if natural reproduction of aquaculture-Escaped Atlantic salmon in a coastal British Columbia river," Conservation Biology 14, 899-903.

Walton, W. C., MacKinnon, C., Rodriguez, L. F., Proctor, C., and Ruiz, G. M. (2002). "Effect of an invasive crab on a marine fishery: Green crab, Carcinus maenas, predation upon a venerid clam, Katelysia scalarina, in Tasmania (Australia)," Journal of Experimental Marine Biology and Ecology 272, 171189. 
Ward, R. D., and Andrew, J. (1996). "Biochemical genetics of the introduced marine fanworm Sabella spallanzanii," Centre for Research on Introduced Marine Pests, Technical Report 8. CSIRO, Division of Fisheries.

Ware, C., Harding, J. M., and Mann, R. (2001). "Temporal and spatial variation in egg cases of Rapana venosa from the Chesapeake Bay, U.S.A." Second International Conference on Bioinvasions. 2001, New Orleans, LA. Available online at http://massbay.mit.edu/exoticspecies/conferences/2001.

Werner, I., and Hollibaugh, J. T. (1993). "Pomatocorbula amurensis: Comparison of clearance rates and assimilation efficiencies for phytoplankton and bacterioplankton," Limnology and Oceanography 38, 949-964.

Westcott, E., Mann, R., and Harding, J. M. (2001). "Reproductive biology of Chesapeake Bay, U.S.A., veined rapa whelks Rapana venosa." Second International Conference on Bioinvasions. 2001, New Orleans, LA. Available online at http://massbay.mit.edu/exoticspecies/conferences/2001.

Whitfield, P. E., Gardner, T., Vives, S. P., Gilligan, M. R., Courtenay, W. R., Ray, G. C., and Hare, J. A. (2002). "Biological invasion of the Indo-Pacific lionfish Pterois volitans along the Atlantic Coast of North America," Marine Ecology Progress Series 235, 289-297.

Whitlach, R. B., and Obrenski, S. (1980). "Feeding selectivity and coexistence in two deposit-feeding gastropods," Marine Biology 58, 219-225.

Whitlow, W. M. (1999). "The impact of Carcinus maenas on patterns of Mya arenaria survivorship." First National Conference on Marine Bioinvasions. January 24-27, 1999. Cambridge, MA. Available online at: http://massbay.mit.edu/exoticspecies/conferences/1999.

Whitlow, W. M., and Dochtermann, J. (2001). "Phenotypic plasticity of native soft-shell clams in response to chemical and physical stimuli from invasive green crab predation." Second International Conference on Bioinvasions. 2001, New Orleans, LA. Available online at http://massbay.mit.edu/ exoticspecies/conferences/2001.

Williams, A. B., and McDermott, J. J. (1990). “An Eastern United States record for the Western Indo-Pacific crab, Hemigrapsus sanguineus (Crustacea: Decapoda: Grapsidiae)," Proceedings of the Biological Society of Washington 103, 108-109.

Williams, J. D., and Meffe, G. K. (1999). "Nonindigenous Species," Status and trends of the nation's biological resources. United States Geological Service. Available on-line at http://biology.usgs.gov/s+t/SNT/index.htm.

Willamson, M., and Fritter, A. (1996). "The varying success of invaders," Ecology 77, 1661-1666. 
Wilson, E. O. (1989). "The coming pluralization of biology and the stewardship of systematics," BioScience 39, 242-245.

Wing, B. L., Guthrie, C. M., and Gharrett, A. J. (1992). "Atlantic salmon in marine waters of Southeastern Alaska." Transactions of the American Fisheries Society 121, 814-818.

Winston, J. E., and Metzger, K. L. (1998). "Trends in taxonomy revealed by the published literature," BioScience 38, 125-128.

Wolfe, L. M. (2002). "Why alien invaders succeed: support for the escape-fromenemy hypothesis," American Naturalist 160, 705-711.

Wolff, W. J. (1999). "Exotic invaders of the meso-oligohaline zone of estuaries in the Netherlands: Why are there so many? "Helogolander Meeresuntersuchungen 52, 393-400.

Wolff, W. J., and Reise, K. (2002). "Oyster imports as a vector for the introduction of alien species into northern and western European coastal waters." Invasive species of Europe-Distribution, Impact and Management. E. Leppakoski, S. Gollash, S. Olenin, ed., Kluwer Academic Publishing, Dordrecht, 193-205.

Wonham, M., O'Connor, M., and Harley, C. (2003). "Multiple positive interactions among mudflat invaders." Third International Conference on Bioinvasions. March 16-19, 2003, La Jolla, CA. Available online at http://massbay.mit.edu/exoticspecies/conferences/2003.

Wynn, S., Hess, L., and Liston, C. (1999). "The invasion of the Chinese Mitten Crab and its effects on fish protection facilities." First National Conference on Marine Bioinvasions. January 24-27, 1999. Cambridge, MA. Available online at: http://massbay.mit.edu/exoticspecies/conferences/1999.

Yamada, S. B. (1982). "Growth and longevity of the mud snail Batillaria attramentaria," Marine Biology 67, 187-192.

Yamada, S. B., Kalin, A., and Hunt, C. (2001). "Growth and longevity of the European green crab Carcinus maenas, in the Pacific Northwest." Second International Conference on Bioinvasions. 2001, New Orleans, LA. Available online at http://massbay.mit.edu/exoticspecies/conferences/2001.

Zabin, C. J. (2003). "Biotic and abiotic factors in the invasion success of a Caribbean barnacle in Hawaii." Third International Conference on Bioinvasions. March 16-19, 2003, Scripps Institution of Oceanography, La Jolla, CA. Available online at http://massbay.mit.edu/exoticspecies/ conferences/2003/index.html.

Zabin, C. J., and Hadfield, M. G. (2001). "Locals only: are intertidal animals limiting the spread of a Caribbean barnacle in Hawaii?" Second International 
Conference on Bioinvasions. 2001, New Orleans, LA. Available online at http://massbay.mit.edu/exoticspecies/conferences/2001. 


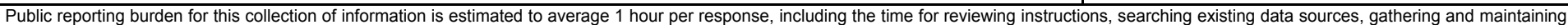

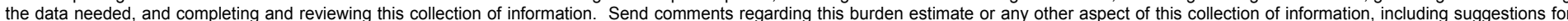

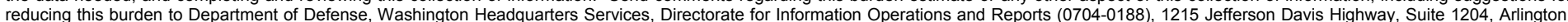

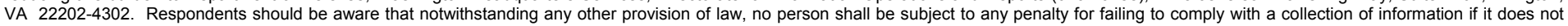
display a currently valid OMB control number. PLEASE DO NOT RETURN YOUR FORM TO THE ABOVE ADDRESS.
1. REPORT DATE (DD-MM-YYYY)
January 2005

4. TITLE AND SUBTITLE
3. DATES COVERED (From - To)

5a. CONTRACT NUMBER

5b. GRANT NUMBER

5c. PROGRAM ELEMENT NUMBER

5d. PROJECT NUMBER

5e. TASK NUMBER

5f. WORK UNIT NUMBER

8. PERFORMING ORGANIZATION REPORT NUMBER

ERDC/EL TR-05-2

U.S. Army Engineer Research and Development Center

Environmental Laboratory

3909 Halls Ferry Road

Vicksburg, MS 39180-6199

\section{SPONSORING / MONITORING AGENCY NAME(S) AND ADDRESS(ES)}

Headquarters, U.S. Army Corps of Engineers

CECW-EW

Washington, DC 20314-1000
10. SPONSOR/MONITOR'S ACRONYM(S)

11. SPONSOR/MONITOR'S REPORT NUMBER(S)

\section{DISTRIBUTION / AVAILABILITY STATEMENT}

Approved for public release; distribution is unlimited.

\section{SUPPLEMENTARY NOTES}

\section{ABSTRACT}

Every year new animal species are inadvertently or intentionally introduced into the marine and estuarine waters of the United States. Originating overseas and from other U.S. waters, invasive species have the potential to disrupt local ecosystems, fisheries, and human infrastructure. Biological invasions directly impact the mission of the U.S. Army Corps of Engineers (USACE) through its responsibilities in maintenance of our nation's waterways, erosion control, water resource management, and estuarine and marine habitat restoration. This report describes the biology and ecology of invasive marine animals and identifies specific organisms that may pose a threat to USACE activities. This includes species already established in U.S. waters and those not yet present that are likely to pose a threat if introduced.

\section{SUBJECT TERMS}

Animals

Estuarine

16. SECURITY CLASSIFICATION OF:

\begin{tabular}{|l|l|l|}
\hline $\begin{array}{l}\text { a. } \text { REPORT } \\
\text { UNCLASSIFIED }\end{array}$ & b. ABSTRACT & c. THIS PAGE \\
UNCLASSIFIED & UNCLASSIFIED \\
\hline
\end{tabular}

Invasive Species

Marine

(20)

7. LIMITATION OF ABSTRACT
NIS

Nonindigenous Species

\begin{tabular}{l|l}
\begin{tabular}{l|l} 
18. NUMBER \\
OF PAGES
\end{tabular} & $\begin{array}{l}\text { 19a. NAME OF RESPONSIBLE } \\
\text { PERSON }\end{array}$ \\
\cline { 2 - 2 } 64 & $\begin{array}{l}\text { 19b. TELEPHONE NUMBER (include } \\
\text { area code) }\end{array}$ \\
&
\end{tabular}

